\title{
Foucault and Marxism: rewriting the theory of historical materialism
}

\author{
MARK OLSSEN \\ University of Surrey, United Kingdom
}

\begin{abstract}
This article explores the relationship of Foucault to Marxism. Although he was often critical of Marxism, Foucault's own approach bears striking parallels to Marxism, as a form of method, as an account of history, and as an analysis of social structure. Like Marxism, Foucault represents social practices as transitory and all knowledge and intellectual formations as linked to social relations and power. In this he asserts the historical relativity of all systems and structures - of society, of thought, of theory and of concepts, while at the same time not denying a materialism of physical necessities. Yet while Foucault's approach reveals these important similarities to Marxism, the differences, claims the author, are fundamental. These concern his rejection of Hegel's conceptions of history and society as a unified developing totality, his rejection of essences and teleology, and his rejection of any utopian impulse revolving around the laws of economic development or the role of the proletariat in history. Foucault's own conception of change, in fact, is represented in ways that are altogether different to Marx's approach, and ultimately supports localistic forms of resistance and specific forms of democratic incrementalism, rather than revolutionary or totalistic strategies as the basis of transforming society.
\end{abstract}

Gérard Raulet: 'But does this reference ... mean that, in a certain way, Marx is at work in your own methodology?' Michel Foucault: 'Yes, absolutely'. (Foucault, 1988, p. 46)

I have never been a Freudian, I have never been a Marxist, and I have never been a structuralist. (Foucault, 1988, p. 22)

This article explores the relationship of Foucault to Marxism. Although he was often critical of Marxism, Foucault's own approach bears striking parallels to Marxism, as a form of method, as an account of history, and as an analysis of social structure. If Foucault's worldly post-structuralism can be represented, as Poster (1984), Rabinow (1984), and I (Olssen, 1999) have argued, as a form of both historical and materialist analysis, the questions I will start this article with are, how does Foucault's form of historical materialism differ from that of Marx, and, to the extent he does differ, what alternative conceptions does he embrace?

\section{Marxist Preliminaries: a brief summation}

Marx's economic discourse comes under the rules of formation of the scientific discourses that were peculiar to the nineteenth century ... Marxist economics - through its basic concepts and the general rules of its discourse - belongs to a type of discursive formation that was defined around the time of Ricardo. (Foucault, 2001, p. 269)

In the Marxist conception of historical materialism, discourse is represented as part of the superstructure which is split from material practice (the economic base) and subordinated to it. In the same way, the mental operations of consciousness are represented as derivative from the 
material base of society. The most famous expression of Marx's conception is from the Preface of $A$ Contribution to the Critique of Political Economy (Karl Marx, 1904, pp. 11-12):

In the social production which men carry on they enter into definite relations that are indispensable and independent of their will; these relations of production correspond to a definite stage of development of their material powers of production. The sum total of these relations of production constitutes the economic structure of society - the real foundation, on which rise legal and political superstructures and to which correspond definite forms of social consciousness. The mode of production in material life determines the general character of the social, political and spiritual processes of life. It is not the consciousness of men that determines their existence, but on the contrary, their social existence determines their consciousness. At a certain stage of their development, the material forces of production in society come in conflict with the existing relations of production, or - what is but a legal expression for the same thing - with the property relations within which they had been at work before. From forms of development of the forces of production these relations turn into their fetters. Then comes a period of social revolution. With the change of the economic foundation the entire immense superstructure is more or less rapidly transformed. In considering such transformations the distinction should always be made between the material transformation of the economic conditions of production which can be determined with the precision of natural science, and the legal, political, religious, aesthetic, or philosophic - in short, ideological forms in which men become conscious of this conflict and fight it out ... . No social order ever disappears before all the productive forces, for which there is room in it, have been developed; and new higher relations of production never appear before the conditions of their existence have matured in the womb of the old society. Therefore, mankind always takes up only such problems as it can solve; since, looking at the matter more closely, we will always find that the problem itself arises only when the material conditions necessary for its solution already exist or are at least in the process of formation.

That Marx's formulation led to charges of economic determinism is evident from the political debates of his own day. Joseph Bloch had levelled such a charge, and in replying to Bloch's accusations in 1890 Engels (1978, pp. 760-761) sought to defend Marx’s conception:

According to the materialist conception of history, the ultimately determining element in history is the production and reproduction of real life. More than this neither Marx nor I have ever asserted. Hence if somebody twists this into saying that the economic element is the only determining one, he transforms that proposition into a meaningless, abstract, senseless phrase. The economic situation is the basis, but the various elements of the superstructure: political forms of the class struggle and its results, to wit: constitutions established by the victorious class after a successful battle, etc., juridical forms, and then even the reflexes of all these actual struggles in the brains of the participants, political, juristic, philosophical theories, religious views and their further development into systems of dogmas, also exercise their influence upon the course of the historical struggles and in many cases preponderate in determining their form. There is an interaction of all these elements in which, amid all the endless host of accidents ... the economic movement finally asserts itself as necessary.

In the twentieth century one of the central issues addressed by Western Marxists has been an attempted resolution and reconceptualisation of the nature of the relation between the economic base and the cultural superstructure of society. In the classical Marxist model both the character of a society's culture and institutions, as well as the direction set for its future development, are determined by the nature of the economic base, which can be defined as the mode of production at a certain stage of development (Williams, 1980, p. 33).

The simplest nature of this relation, as Williams (1980, p. 33) tells us, was one of 'the reflection, the imitation, or the reproduction of the reality of the base in the superstructure in a more or less direct way'; that is, a relation in which the economic base and specifically the forces of production constituted the ultimate cause to which the social, legal and political framework of the society can be traced back. 
In the attempt to reformulate Marxism in the twentieth century the economic determinist conception was challenged by those who saw Marxism as granting rather more 'independence' or 'autonomy' to the superstructures of society. Hence a 'dialectical' notion of the relation was stressed, suggesting a relation of reciprocal influence. It was argued that, although the base conditions and affects the superstructure, it is in turn conditioned and affected by it. In all cases, however, in order to remain as Marxists, the ultimate priority of the economic base as the causal determinant of the social character of a society was safeguarded by maintaining that the economic factor is 'determining in the last instance'. Hence, it was maintained that the superstructure had only a 'relative autonomy', and the theory of 'relative autonomy', as a shorthand designation of the base-superstructure relation, became a central concept of twentieth-century Marxism.

There were, of course, other attempted formulations of the process of determination and of the relations or mode of interaction between economic and cultural phenomena in a society. Some of these sought to replace, or go beyond, the topographical metaphor of base and superstructure with its suggestion of a definite dichotomous spatial relationship, and conceptualise the issue of determination in altogether different ways. In his own summary of the qualifications and amendments introduced by twentieth-century Marxists, usually claiming to clarify Marx's true and original intentions, Williams (1980, pp. 32-33) points out that:

The first kind of qualification had to do with delays in time, with complications, and with certain direct or relatively distant relationships. ... The second stage was related but more fundamental in that the process of the relationship itself was more substantially looked at. This was the kind of reconsideration which gave rise to the notion of 'mediation', in which something more than simple reflection or reproduction - indeed something radically different from either reflection or reproduction - actually occurs. In the later twentieth century there is the notion of 'homologous structures', where there may be no direct or easily apparent similarity, and certainly nothing like reflection or reproduction, between the superstructural process and the reality of the base, but in which there is an essential homology or correspondence of structures, which can be discovered by analysis. This is not the same notion as 'mediation', but it is the same kind of amendment in that the relationship between the base and the superstructure is not supposed to be direct, nor simply operationally subject to lags and complications and indirectnesses, but that of its nature it is not direct reproduction.

In his own attempted reformulation, Williams (1980, p. 34) argues that:

We have to revalue 'determination' towards the setting of limits and the exertion of pressure and away from a predicted, prefigured and controlled content. We have to revalue 'superstructure' towards a related range of cultural practices, and away from a reflected, reproduced or specifically dependent content. And, crucially, we have to revalue 'the base' away from the notion of a fixed economic or technological abstraction, and towards the specific activities of men in real social and economic relationships, containing fundamental contradictions and variations and therefore always in a state of dynamic process.

Notions of 'totality' (associated with Lukács), or of 'hegemony' (associated with Gramsci), or of society as a 'complex whole' (associated with Althusser), constitute attempts to move beyond simple dichotomous models of base and superstructure. In Althusser's conception, the social structure, represented as a 'complex whole structured in dominance' is characterised by a series of levels of practices, including the level of science or theoretical practice, the level of ideological practice, the level of political practice, and the level of economic practice. Althusser argues for the primacy of practice 'by showing that all the levels of social existence are the sites of distinct practices' (Althusser, 1970, p. 58) and claims that Marx's achievement was to found 'a historico-dialectical materialism of praxis: that is ... a theory of the different specific levels of human practice' (Althusser, 1969, p. 169; emphasis in original).

The determination of events and processes was theorised using the concept of overdetermination, a concept which Althusser borrowed from Freud, and which indicates a process of the complex and multiple causation of events whereby a causal contribution is made by all of the levels, the relative importance of any level in any particular instance varying according to time and place. Theorised in this way, Althusser argues that the non-economic practices have a specific effectivity which means 
that they are determining as well as determined, just as economic practices are determining as well as determined. What it also means is that every aspect or part contributes in its own right to determining the character of the overall whole of which it is a part, as well as being shaped by it in turn. In the same way, rather than characterising contradictions as singularly concerned with the economic forces and relations of production, there is in Althusser's conception a multiplicity of contradictions occurring at all levels of the social formation. In this sense, determination is never simple, but rather, complex and multiple. Again, however, in order to retain his link to Marxism, and to differentiate his own theory of social structure from non-Marxist theories of systems functionalism, Althusser argues that economic practice is fundamental and is 'determining in the last instance'. Although the economy is 'determining in the last instance', it is not always the dominant structure, however. The apparent paradox is explained because the economy determines which of the other elements will be dominant. That is, it determines for the non-economic levels their respective degrees of autonomy or dependence in relation to each other and to itself, and thus the different degrees of effect that each will have. It can determine itself as dominant or nondominant at any particular time. At a particular juncture one element may displace another to assume the dominant role. In addition, different elements can be dominant in different societies, or at different times. Hence, this is what Althusser intends when he refers to the social formation as a structure in dominance.

After 1968, says Poster, Foucault attempted to come to grips with Marxist scholarship, and while the positions he adopted in some cases resembled those of Western Marxists, generally he went beyond those positions towards a new formulation of critical theory. Although Foucault rejects Marxism as a specific theory of the mode of production, as a critique of political economy, or as a dialectical method, he advances a critical view of domination which, like historical materialism, takes all social practices as transitory, and all intellectual formations as indissociably connected with power and social relations (Poster, 1984, pp. 39-40). Poster explains what he sees as Foucault's greater relevance than Marxism in terms of a shift from nineteenth- and early twentiethcentury forms of capitalism based upon the 'mode of production' to new forms of later twentiethcentury capitalism based upon the 'mode of information'. These changes were associated, says Poster, with changes in the nature of the economy, an increase in the service and white collar sectors, the increasing development of information technology, developments in electronic communications, together with new possibilities that these developments generate for a decentralisation of political power. While Marxism's focus on labour and the central causal priority of the economy may have had heuristic value in the age of ascendant capitalism, in an era of 'information capitalism' historical materialism finds its premise in power that is the effect of 'discourse/practice'. Thus, according to Poster:

the couplet discourse/practice ... enables [Foucault] to search for the close connection between manifestations of reason and patterns of domination. Foucault can study the way in which discourse is not innocent, but shaped by practice, without privileging any form of practice such as class struggle. He can also study how discourse in turn shapes practice without privileging any form of discourse. (Poster, 1984, p. 12)

Foucault thus rejects Marx's conception of historical materialism as a mechanism by which discourse is split from material (non-discursive) practice and by which the former is then subordinated to the latter. By representing the mental operations of consciousness as derivative from the material base of society, Marx, for Foucault, remains firmly fixed within a traditional enlightenment problematic (Poster, 1984, pp. 16-18).

\section{Reconceptualising Determination}

Foucault rejects Marxist models of a determining economic base and a determined superstructure as well as refinements based on conceptions of totality by Marx's twentieth-century successors. Like Bourdieu and Althusser, he retains a concept of practice, however, and utilises the concept of strategies to understand how practice is operationalised and how people act on their environments. To some extent, the concept enabled Foucault to distance himself from structuralism and to see practice as something not entirely the result of rational calculation. As a series of strategies, Foucault sees power as mobilised, and he utilises the strategic metaphor of the game, in reference 
to both language and power: 'Language it is played ... Relations of power, also, they are played; it is these games of power (joux de pouvoir) that one must study in terms of tactics and strategy, in terms of order and of chance, in terms of stakes and objectives' (Foucault, 1994a, 3, pp. 541-542). The game is a useful metaphor for Foucault. In a game one is both free and constrained. Players find themselves at points where they must respond (e.g. when the ball that has been kicked by the opponent lands). In addition, movements in a game are infinitely variable. While players are confined by rules, indefinite number of possibilities and options exist within them. In addition, through effective strategies players can utilise the rules to their own advantage; they can invent and improvise; within a system of constraints moves are numerous.

Foucault is not interested in accounting for such practices in terms of a model of economic determination. Although, like Althusser, he utilises a model of complex and multiple causation and determination within the social structure, the specific elements and mechanisms of such processes, as elaborated by Foucault, differ in important, indeed crucial, respects. In Foucault's materialism, explaining the relations between discursive formations and non-discursive domains (institutions, political events, economic practices and processes) is recognised as the ultimate objective, at least from the time of The Archaeology of Knowledge. For archaeology, in comparison to Marxism, however, 'The rapprochements are not intended to uncover great cultural continuities, nor to isolate mechanisms of causality ... nor does it seek to rediscover what is expressed in them ... it tries to determine how the rules of formation that govern it ... may be linked to non-discursive systems: it seeks to define specific forms of articulation' (Foucault, 1972, p. 162). Unlike Marxists, he sees no one set of factors as directing human destiny. Rather, the forms of articulation and determination may differ in relation to the relative importance of different non-discursive (material) factors in terms of both place and time. In the shift from a purely archaeological to a genealogical mode of enquiry, Foucault's concern with the relation between discursive and non-discursive domains is given a more historical and dynamic formulation, although the concern with synchronic analysis is not abandoned. Throughout, however, as Mark Poster (1984, pp. 39-40) explains, Foucault's central aim is to provide a version of critical theory in which the economic base is not the totalising centre of the social formation, whereby Hegel's evolutionary model of history is replaced by Nietzsche's concept of genealogy, and where causes and connections to an imputed centre or foundation are rejected in favour of exposing the contingency and transitory nature of existing social practices. In Poster's (1984, pp. 39-40) view, this presents us with a crucial decision. In comparing Foucault and Althusser, he maintains that 'the theoretical choice offered by these two theorists is dramatic and urgent. In my opinion Foucault's position in the present context is more valuable as an interpretative strategy ... Foucault's position opens up critical theory more than Althusser's both to the changing social formation and to the social locations where contestation actually occurs'. While having a generally historicised view of the nature and development of knowledge, Foucault rejects the possibility of any 'absolute' or 'transcendental' conception of truth 'outside of history' as well as of any conception of 'objective' or 'necessary' interests which could provide a necessary 'Archimedean point' to ground either knowledge, morality or politics. Read in this way, historical materialism is about the systematic character of society and how it might change. It is about the processes of change internal to social systems. It holds that societies are to varying extents integrated systematically through their material practices and discursive coherences, and break down and change as the component elements of the system change.

\section{Change and Determination}

The notion of change is central to the difference between Foucault and Marxism, for the understanding of change is linked closely to the issue of the status of causal explanations. For Marxism, in the main, with the partial exception of Althusser's structuralist version, the conception of change is that of Newton and the Enlightenment, which had been applied to both the natural and the social sciences. Although Althusser developed a model of complex causation, whereby the specific effectivity of structures depended upon specific historical conditions, the fact that he underwrote his theory with a conception of the economic as the final ultimate determinant made his own approach consistent with this Enlightenment view. This was a linear and individualist conception of cause and effect between objects whose self-determined essences collide and interact 
with predictable consequences. For Foucault, such an approach not only implied a conception of change and causality which he found problematic, but with respect to Marxism specifically, it was associated by topographical and architectural metaphors, between deep/surface or base/superstructure which sat uncomfortably with his own preference for analysing the micropractices of lived experience.

Foucault's approach to structuralism and change led him to question the central importance of humanism or the individual human subject as a means by which to understand change. While political liberals may well seek to account for change in terms of voluntary theory of human agency, for Foucault, what was significant about structuralism was the analysis of the internal laws of structures. As he puts it in 'Interview avec Michel Foucault' of 1968, reproduced in Dits et écrits (Foucault, 1994c, 1, p. 654):

In a positive manner, we can say that structuralism investigates above all an unconscious. It is the unconscious structures of language, of the literary work, and of knowledge that one is trying at this moment to illuminate. In the second place, I think that one can say that what one is essentially looking for are the forms, the system, that is to say that one tries to bring out the logical correlations that can exist among a great number of elements belonging to a language, to an ideology (as in the analyses of Althusser), to a society (as in Lévi-Strauss), or to different fields of knowledge; which is what I myself have studied. One could describe structuralism roughly as the search for logical structures everywhere that they could occur.

Structural linguistics thus served as a model for his analysis of the human sciences. His major work on linguistic method and the methodology of the social sciences appears in his 1969 article 'Linguistique et sciences sociales', reproduced in Dits et écrits, where he discusses the epistemological issues concerned with the social sciences. In opposing the linear notions of determination dominant in the Enlightenment, and in Marxism, structural linguistics, he says (1994b, 1, p. 824), is concerned with 'logical relations' between elements. These 'logical relations' are essentially 'multiple relations'. They are ontologically separate from the elements to which they pertain, and they derive from the collective interactions between elements. Hence, he says (1994b, 1, p. 824), it is the 'presence of a logic that is not the logic of causal determinism that is currently at the heart of philosophical and theoretical debates'.

Foucault's reliance on the model of structural linguistics provides him with a method which avoids both methodological individualism and being trapped by a concern with causalism. Structural linguistics is concerned with 'the systematic sets of relations among elements', and it functions for Foucault as a model to enable him to study social reality as a logical structure, or set of logical relations revealing relations that are not transparent to consciousness. The methods of structural linguistics also enable Foucault to analyse change. For just as linguistics undertakes synchronic analysis seeking to trace the necessary conditions for an element within the structure of language to undergo change, a similar synchronic analysis applied to social life asks the question, in order for a change to occur, what other changes must also take place in the overall texture of the social configuration (Foucault, 1994b, 1, p. 827). Hence, Foucault seeks to identify logical relations where none had previously been thought to exist or where previously one had searched for causal relations. This form of analysis becomes for Foucault a method of analysing the multifaceted yet invisible determinations within the social structure.

The methodological strategies common to both archaeology and genealogy were also developed in response to Marxism, which is characterised by a specific narrow conception of causality (un causalisme primaire) and a dialectical logic that has very little in common with the logical relations that Foucault is interested in. Thus, he maintains, "what one is trying to recover in Marx is something that is neither the determinist ascription of causality, nor the logic of a Hegelian type but a logical analysis of reality' (Foucault, 1994b, 1, pp. 824-825). To seek to uncover 'logical relations' instead of linear, atomistically conceived cause-effect determinations is to provide a major rupture from Marxist analysis of base and superstructure, especially with respect to articulating the nature of the determinations present. Foucault is adamant that his concern with analysing logical relations is qualitatively different to the sorts of causal analysis that characterises Marxist and dialectical logics, even those analysed by Althusser.

Arnold Davidson (1997), in a review of Dits et écrits to which my own analysis is indebted, points out that it is through such methodological strategies that Foucault proceeds to advance a non- 
reductive, holist, analysis of social life. As he puts it (1997, p. 11), 'this kind of analysis is characterised, first, by anti-atomism, by the idea that we should not analyse single or individual elements in isolation but that one must look at the systematic relations among elements; second, it is characterised by the idea that the relations between elements are coherent and transformable, that is, that the elements form a structure'. In this sense, says Davidson (1997, p. 10)

The status of causal explanations is connected to the problem of how to account for change ... As Foucault points out, we should not identify history with the dimension of the successive since 'the simultaneity of two events is no less an historical fact than their succession'. Moreover, according to Foucault, the synchronic analysis done by linguists is in reality an analysis 'of the conditions of change' where the dimension of change must not be confused with that of cause ... Foucault always insisted that causal relations represented only one kind of change and that one should not collapse the different types of changes into a single level. Foucault claimed that it was the humanist Marxists, like Sartre and Roger Garaudy, who insisted that one speak exclusively of causality and who therefore wanted to impose a reduction of 'the field of exploration' ... . Furthermore, in practice the search for causality always risked losing itself in 'a more or less magic fog' ...; notions like the spirit of the times, influence, social change, crisis, interest, all of which were supposed to have some causal force, seemed to Foucault to provide explanations 'for the most part, more magic than real' ... . As Foucault indicated, causal explanations aside, 'change can be an object of analysis in terms of structure'.

This sort of approach accounts for one of the major differences between Foucault and Marxism, and also from individualist traditions in Anglo-American social science. Thus, in his dissertation on the knowledge of heredity as a system of thought, submitted as part of his application for his position at the Collège de France, Foucault seeks to describe the changes, transformations, and conditions of possibility that made genetics possible, that constituted it as a science based on a series of discourses concerning breeding, just as in The Order of Things he had done for natural history and biology. What factors led to the emergence of these fields as sciences? What elements changed to make such developments possible? What made them possible as systems of thought? Thus, Foucault seeks to describe the relations among elements as structures which change as the component elements change, i.e. he endeavours to establish the systematic sets of relations and transformations that enable different forms of knowledge to emerge.

\section{Monism and Pluralism}

In as much as Foucault was influenced by structuralism, he of course adamantly denied being a structuralist, and it is the sense in which he departs from structuralism that reinforces his commitments to a less deductive, more pluralist mode of approach, inspired by Nietzsche. There are a number of senses. First, Foucault rejected the notion central to structuralism of a system of universal rules, or laws, or elementary structures, that underpinned history and explained its surface appearances. When it is noted in the final dialogue of The Archaeology of Knowledge (1972, pp. 199-200) that 'throughout this book, you have been at great pains to dissociate yourself from structuralism', the other Michel says, 'I reject a uniform model of temporalization, in order to describe, for each discursive practice, its rules of accumulation, exclusion, reactivation, its own forms of derivation, and its specific modes of connexion over various successions'. Foucault always stood opposed to a marked tendency among structuralist writers to prioritising the structure over the parts, whereby the units could be explained once the essence of the structure is uncovered. The failure to theorise adequately the historicity of structures was in fact common to both structuralists and Marxists, as both adopted ahistorical and uniform models of temporalisation and change. In retrospect, one can see that even when Foucault's methodological focus privileged archaeology, prior to the 1970s, it was within the context of historically constituted epistemes, and the difference of his position to structuralism was already manifest in relation to several key dimensions - the thesis which is set out explicitly in The Archaeology of Knowledge.

Closely related to the senses in which Foucault rejected structuralism, a central element of his critique of Marxism relates to the notion of 'totalisation'. Essentially, for Foucault, Marxism was not just a 'deterministic' but a 'deductivistic' approach. That is, it directs attention not just to the 
primacy of the economy but it seeks to explain the parts of a culture as explicable and decodable parts of the whole totality or system. Marxism, claims Foucault, seeks to ascertain 'the principle of cohesion or the code that unlocks the system explaining the elements by deduction' (Thompson, 1986, p. 106). This is an approach which seeks to analyse history and society in terms of 'totality', where the parts are an 'expression' of the whole - hence the notion of an 'expressive totality'.

Of central importance in Hegel is the conception of society as a closed and bounded totality. For Hegel this was an expressivist notion where society expresses the inner essence of its subject in a process of continuous unfolding by which reason realises itself in history. The essence manifests its appearance in different ways at different times, becoming more exposed in the process of history. In this model there is a tendency to conceptualise society as a potentially unified subject with a unified will and, thus, considerations of pluralism in any of its forms - social, political, or cultural become problematic. Similarly, there is too much reliance in Marxism on forms of analysis, particularly class analysis, in establishing the causes and conditions of oppression in existing social orders. Further, both Hegel and Marx subscribed to a philosophy of history that underplayed the roles of contingency, locality, chance and identity in struggles against oppressive power. As a consequence, for Marxism, every aspect of capitalist society - every institution, social form, or relationship - becomes an expression of the inner essence.

In countering this Hegelian emphasis, Foucault (1972, pp.9-10) draws a distinction between 'total history' and 'general history'. The central differences are:

The project of total history is one that seeks to reconstitute the overall form of a civilization, the principle - material or spiritual - of a society, the significance common to all the phenomena of a period, the law that accounts for their cohesion ... . A total description draws all phenomena around a single centre - a principle, a meaning, a spirit, a world-view, an overall shape ... it is supposed that between all the events of a well-defined spatiotemporal area, between all the phenomena of which traces have been found, it must be possible to establish a system of homogeneous relations: a network of causality that makes it possible to derive each of them, relations of analogy that show they symbolize one another or how they all express one and the same central core; it is also supposed that one and the same form of historicity operates upon economic structures, social institutions and customs ... and subjects them all to the same type of transformation; lastly, it is supposed that history itself may be articulated into great units - stages or phases - which contain within themselves their own principle of cohesion ...[G]eneral history, on the contrary, would deploy the space of dispersion ... it speaks of series, divisions, limits, differences of level, shifts, chronological specificities, particular forms of rehandling, possible types of relation ... The problem ... which defines the task of general history is to determine what form of relation may be legitimately described between these different series.

Whereas total history seeks to explain all phenomena in relation to a single centre, general history employs the space of dispersion. It represented a 'new history' (1972, p. 9) characterised by 'a general theory of discontinuity, of series, of limits, unities, specific orders and differentiated autonomies and dependences' (p. 12), in contrast to 'history in its traditional form' (p. 7) which is based on a model of 'the continuous chronology of reason' and the correlative founding function of the subject (p.12). The methodological task for general history is the empirical establishment of interconnections in order to 'determine what form of relation may be legitimately described between these different series' (p. 10).

For Foucault, the explanatory quest is not to search for the organising principle of a cultural formation - whether the 'economy', or the 'human subject' or the 'proletariat'. Rather, Foucault is interested in advancing a polymorphous conception of determination in order to reveal the 'play of dependencies' in the social and historical process. As he puts it in an article written in 1968 and translated and printed in English in 1978, 'I would like to substitute this whole play of dependencies for the uniform simple notion of assigning causality and by suspending the indefinitely extended privilege of the cause, in order to render apparent the polymorphous cluster of correlations' (Foucault, 1978, p. 13).

For Foucault (1978, p. 13), there were three aspects to the play of dependencies: firstly, the intradiscursive, which concerns relations between objects, operations and concepts within the discursive formation; secondly, the interdiscursive, which concerns relations between different 
discursive formations; and, thirdly, the extradiscursive, concerning the relations between a discourse and the whole play of economic, political and social practices. Rather than seek to find the articulating principle of a cultural complex, Foucault was interested in discerning how cultural formations were made to appear 'rational' and 'unified', how particular discourses came to be formed, and what rules lay behind the process of formation. In doing so he sought to produce accounts of how discursive formations like nineteenth-century psychopathology came to be formed, how it constituted its scientific legitimacy and shaped the thinking of a particular period. Thus, in the case of nineteenth-century psychiatry and psychopathology, Foucault shows how the term 'madness' came to be applied to certain types of behaviour, and how, in its very designation by what it wasn't, it helped establish our conceptions of 'the rational' and 'the sane'.

What Foucault resists, however, in all of these studies, is the temptation to try to explain the development of particular discursive formations as a result of any single cause or principle. In opposition to the themes of totalising history, with its notions of 'the progress of reason' and 'the sprit of a century', Foucault (1978, p. 10) substitutes what he calls a differentiated analysis:

Nothing, you see, is more foreign to me than the quest for a sovereign, unique and constraining form. I do not seek to detect, starting from diverse signs, the unitary spirit of an epoch, the general form of its consciousness: something like a Weltanschauung. Nor have I described either the emergence and eclipse of formal structure which might reign for a time over all the manifestations of thought: I have not written the history of a syncopated transcendental. Nor, finally, have I described thoughts or century-old sensitivities coming to life, stuttering, struggling and dying out like great phantoms - ghosts playing out their shadow theatre against the backdrop of history. I have studied, one after another, ensembles of discourse; I have characterised them; I have defined the play of rules, of transformations, of thresholds, of remanences. I have established and I have described their clusters of relations. Whenever I have deemed it necessary I have allowed systems to proliferate.

It is the attempt to 'individualise' discourses that defines Foucault's methodological imperative: specifying their systematic and specific character; searching for the rules of formation for all of the concepts, methods, and theoretical postulates; examining the conditions of transformation which are effective, at a precise time, for the operations, concepts, and theories to be formed, or discarded, or modified; and ascertaining their specific existence in relation to other types of discourse.

It is interesting that in the 'Introduction' to The Archaeology of Knowledge Foucault (1972, p. 13) exonerates Marx himself from such a totalising approach to history. Marx is credited as being an exponent of an early (pre-Nietzschean) version of general history involving a 'decentring' based on 'the historical analysis of the relations of production, economic determinations, and the class struggle' (p. 13), whereby Marx sought to identify and analyse 'specific series', 'levels and limits' and 'the whole interplay of differences' in their uniqueness and autonomy (p. 13). But, says Foucault, Marx's own approach 'gave place, towards the end of the nineteenth century, to the search for a total history' (p. 13) whereby 'one is led to anthropologize Marx, to make him a historian of totalities, and to recover in him the meaning of humanism' (p. 13).

In a normative sense, Foucault clearly opposed both political policies and academic approaches that erode difference or diversity. This explains his distaste for Hegelian conceptions of community whereby identity (individual or collective) becomes a shadow of the whole and reducible to it, thus eclipsing individuality, producing a sterile conformity, and eradicating difference. It was for this reason that Foucault opposed utopian theorising, as in Habermas. In Habermas there is the notion of a rationality premised, as Jameson (1984, p. vii) has put it, on the idea of a 'noisefree, transparent, fully communicational society'. As Foucault (1991a, p. 18) states, in relation to this issue:

[In Habermas's work] there is always something which causes me a problem. It is when he assigns a very important place to relations of communication and also to functions that I would call 'utopian'. The thought that there could be a state of communication which would be such that the games of truth could circulate freely, without obstacles, without constraint, and without coercive effects, seems to me to be Utopia. It is being blind to the fact that relations of power are not something bad in themselves, from which one must free oneself. I don't believe there can be a society without relations of power ... . The problem is 
not of trying to dissolve them in the utopia of a perfectly transparent communication, but to give oneself the rules of law, the techniques of management, and also the ethics, the ethos, the practice of self, which would allow these games of power to be played with a minimum of domination.

For Foucault, 'strategic' action, conceived broadly as politically or ideologically distorted dialogue, necessarily supervenes on 'communicative' action. It is always the question of maintaining the correct 'balance of power relations in the present rather than seeking to exclude all forms of power from the world in the search for a different order of society. Hence Foucault rejects the idea, that he sees in Habermas, Marxism, and the Frankfurt School, of conceiving history as a single rational trajectory along which humanity fulfils its essential nature, arriving ultimately at a utopia of 'pure existence' freed from the realities of power or conflict. For Foucault, following Nietzsche, power is more ubiquitous, diffuse, and corporeal; it infiltrates the fine textures of social existence as well as self-identity, and hence it is impossible to know one's true humanity apart from power's distorting effects.

Foucault also gives only qualified support to consensus models of policy making for the same reasons. The issue was put to him in 1983 by a group of interviewers including Paul Rabinow, Charles Taylor, Martin Jay, Richard Rorty, and Leo Lowenthal (Foucault, 1984a, p. 379):

Q. If one can assume that the consensus model is a fictional possibility, people might nonetheless act according to that fiction in such a way that the results might be superior to the action that would ensue from the bleaker view of politics as essentially domination and repression, so that although in an empirical way you may be correct and although the utopian possibility may never be achievable, nonetheless, pragmatically, it might in some sense be better, healthier, freer, whatever positive value one uses, if we assume that the consensus is a goal still to be sought rather than one that we simply throw away and say it's impossible to achieve.

M.F. Yes, I think that is, let us say, a critical principle ...

Q. As a regulatory principle?

M.F. I perhaps wouldn't say regulatory principle, that's going too far, because starting from the point where you say regulatory principle, you grant that it is indeed under its governance that the phenomenon has to be organised, within limits that may be defined by experience or the context. I would say, rather, that it is perhaps a critical idea to maintain at all times: to ask oneself what proportion of nonconsensuality is implied in such a power relation, and whether that degree of nonconsensuality is necessary or not, and then one may question every power relation to that extent. The farthest I would go is to say that perhaps one must not be for consensuality, but one must be against nonconsensuality.

It is linked to such views that in the 1970s he advocated 'localistic' analyses. The issue became contested by Marxist writers who saw in this a certain circumscription of analytical capacity and an inability to deal with the political level. The inability to conceptualise change in a way that transcends localistic issues and links the individual to groups and collective politics is taken up by Duccio Trombadori in his interviews with Foucault in 1978 (see Foucault, 1991b). Trombadori asks:

One of the observations that could be made of the way in which you confront the theme of power is this: the extreme fragmentation or 'localization' of the questions ends up impeding the transition from a dimension that we might even call 'corporate' to a vision of the totality within which the particular problem is inserted. (Foucault, 1991b, p. 150)

Foucault gives a long answer in which he says:

Yes, the problems that I pose are always concerned with local and particular issues ... how could one do otherwise? (pp. 150-151)

To this Trombadori raises an objection:

Perhaps I didn't explain myself. I do not dispute the need to raise local problems, even in a radical way, if it is necessary. Moreover, I am sensitive to what you say about intellectual work. Nevertheless, it seems to me that that way of confronting problems by particularizing 
them ends up inhibiting the possibility of their coordination in relation to other problems in the general understanding (vision) of a determinate historical and political situation. (p. 152)

To this Foucault responds:

Localizing problems is indispensable for theoretical and political reasons. But that doesn't mean that they are not, however, general problems. After all, what is more general in a society than the way in which it defines the relation to madness. (p. 152)

Trombadori is still not satisfied, however:

When I spoke of a general understanding (vision), I was referring essentially to the political immersion of a problem and to the necessity of its articulation in a wider action or program that at the same time is linked to certain historico-political conditions. (p. 153)

To this Foucault responds:

The generality that I try to make apparent is not of the same type as others. And when I am blamed for localizing problems, confusion is created between the local character of my analyses and an idea of generality similar to the one usually discussed by historians, sociologists, economists etc. I don't advance problems that are less general than those usually proposed by political parties or by certain great theoretical systems. (p. 153)

Somewhat frustrated, Trombadori endeavours to restate the problem:

What you say is perfectly acceptable. But you seem to confirm a certain closure, or unwillingness to open your discourse clearly onto the level of the 'political'. (p. 154)

He continues to elaborate in an effort to clarify:

For every local problem one always faces the need to find solutions - even if provisional and temporary ones - in political terms. From this arises the need to shift one's way of seeing things from a particular analysis to the examination of real possibilities, within which a process of change and transformation can advance. It is in this balance between the local situation and the general picture that the 'political' function is at stake. (pp. 156-157)

To which Foucault says:

I would respond in this way: for reasons that essentially pertain to my political choice, in the widest sense of the term, I absolutely will not play the part of one who prescribes solutions. I hold that the role of the intellectual today is not that of establishing laws or proposing solutions or prophesying, since by doing that one can only contribute to the functioning of a determinate situation of power that to my mind must be criticized. (p. 157)

Trombadori remains unsatisfied, however, and asks Foucault whether 'in the long run', by evading in some way the 'political dimension', his proposal 'risks representing a kind of 'distraction', considering the contingent and complex stakes in question that are placed in society but have their immediate reflection on the level of institutions and parties' (p. 164).[1]

It is noteworthy that it was after this interview that Foucault developed the concept of 'governmentality' in the early 1980s in response to criticisms that his conception of power was too 'localistic' and 'regional' and did not take the formation of national and international hegemonies into account, and developed the concept of the 'strategic reversibility of power relations' at the same time, to seek to explain how individuals exert agency drawing on the very discursive systems through which they have been constructed.

In terms of the sociological implications of the principle of totality as utilised by Marxism, Balibar (1992, p. 44) notes that it conveys 'the idea that in the social "whole", the "parts" or the "cells" are necessarily similar to the whole itself. Foucault's objection to this principle on a practical level, i.e. in terms of its implications for actual historical and social research, can be seen in regard to any number of institutional sectors. Balibar gives the example of the family which Foucault analyses in The History of Sexuality, Volume 1. While, typically, Marxists had considered the family reductively as the consumption-hub of bourgeois society, i.e. as purely reproductive of capitalist class relations, for Foucault, the family has more positive functions. As Balibar (1992, p. 44.) points out: 
Foucault stresses the strategic role of the family (its moralisation and its medicalisation) in the apparatus of the regulation of populations which forms one of the essential powers of the 'bourgeois' State; also it is important for him to show that the family is simultaneously the locus of institutional perversion ... the hysterisation of the women's body ... the space which is the opposite to psychiatric space ... the central concern in the competition between holders of professional knowledge about man ... the means of socialising reproductive activity and, in particular, the locus of the juridical 'recoding' of bodily techniques in general into forms of alliance or kinship ... . It is for all these reasons that the family cannot be considered as the reduced image of the global society.

Hence, the family does not reproduce society and the society does not imitate the family. As Balibar states (1992, p. 44), it is "not a monad pars totalis of "the society" and its strategic importance lies not in its resemblance but in the specific nature of its difference. Foucault's criticism of the Marxist use of the concept of power is also related to totalism in that the power of dominant groups is seen in Marxism to 'echo through successive amplifications' throughout the whole social body (Balibar, 1992, p. 44).

\section{Complexity, Chance, Pluralism: appropriating Nietzsche to correct Marx}

The dissociation between structuralism and Marxism, and Foucault's own position became more apparent after Foucault's turn to genealogy and Nietzsche at the close of the 1960s. With his growing interest in genealogy, Foucault became more concerned with power and history, and the historical constitution of knowledge. In this process there was, however, no integrative principle or essence. If the genealogist studies history "he finds that there is "something altogether different" behind things: not a timeless and essential secret, but the secret that they have no essence or that their essence was fabricated in a piecemeal fashion from alien forms' (Foucault, 1977b, p. 142).

Foucault's objection to elements of Marxism explicitly reflects his Nietzschean heritage and his belief that certain aspects of Marxism distorted the liberatory potential of the discourse.

The interest in Nietzsche and Bataille was not a way of distancing ourselves from Marxism or communism - it was the only path towards what we expected from communism.

(Foucault, 2001, p. 249)

It was in terms of the philosophy of difference and Nietzsche's conception of multiplicities through a rejection of Platonic hierarchies that Foucault enunciates a theory of discursive formations and rejects Marxist and Hegelian conceptions of history. The utilisation of Nietzsche signalled a rupture from Marxism in relation to a series of interrelated conceptual, theoretical and methodological percepts, including power, knowledge and truth, the subject, and the nature of historical change and determination.

Nietzsche focussed on power in an altogether different way to Marx. In 'Prison Talk', Foucault (1980b, p. 47) states:

It was Nietzsche who specified the power relation as the general focus, shall we say, of

philosophical discourse - whereas for Marx it was the productive relation. Nietzsche is the philosopher of power, a philosopher who managed to think of power without having to confine himself within a political theory in order to do so.

Power, for Nietzsche, was conceived as a relation of forces within an analytics of power/knowledge/truth, which became important for Foucault to understand in the later 1960s after the publication of The Archaeology of Knowledge and his growing friendship with the Parisian Nietzschean Gilles Deleuze. Foucault accredits Nietzsche as the source of his interest in the question of truth and its relation to power. As he states in 'Truth and Power' (Foucault, 1980a, p. 133), 'The political question ... is not, error, illusion, alienated consciousness or ideology, it is truth itself. Hence, the importance of Nietzsche'. Nietzsche's importance to Foucault can be seen as 'correcting Marx', especially in relation to the linkage between power-knowledge-truth, and the functioning of knowledge as an instrument of power. As Alan Schrift (1995, p. 40) notes, Nietzsche's influence drew attention away from 'substances, subjects and things, and focussed attention instead on the relations between these substantives'. In a related way, Foucault 'draws our 
attention away from the substantive notion of power and directs our attention instead to the multifarious ways that power operates through the social order' (Schrift, 1995, p. 40). For Nietzsche, such relations were relations of forces. Foucault thus focused on new relations as the relations of forces that existed and interacted within social systems as social practices. These were forces of repression and production that characterised the disciplinary society; forces that enable and block, subjugate and realise, and normalise and resist. In this model, power is not a thing, but a process, a becoming.

Beyond these concerns with power-truth-knowledge, and language and discourse, Foucault acknowledges the influence of Nietzsche in reference to the decentring of the subject, and the constitutive ethics of self-creation. In the Genealogy of Morals (1967) Nietzsche traces the processes of descent (Entstehung) and emergence (Herkunft), but distinguishes these from a concern with origins (Ursprung) or essences. Nietzsche's thesis is that the subject is historically constituted and does not exist as something given metaphysically in advance. This is what Nietzsche (1967, pp. 1, 13) means when he says 'there is no "being" behind doing, effecting, becoming; "the doer" is merely the fiction added to the deed - the deed is everything'. For Foucault, accepting this view of the subject, he sees it as an ideological product, an effect of power, whose identity is defined in relation to the functionality of discourse.

The view of history as pluralist and not accounted for within a context of causal iron-law determinism was also important in Foucault's debt to Nietzsche. Whereas Marxists like Althusser adopted a structuralist programme of seeking to explain the whole by understanding the interrelations between its component parts, for Foucault the totality always eluded analysis or understanding in terms of structure, but rather was characterised by incompleteness, indeterminacy, complexity and chance. As Foucault says, 'though it is true that these discontinuous discursive series each have within certain limits, their regularity, it is undoubtedly no longer possible to establish links of mechanical causality, or of ideal necessity between the elements which constitute them. We must accept the introduction of alea (chance) as a category in the production of events' (Foucault, 1981, p. 69).[2]

In seeking to characterise the nature of his 'pluralism' and how it affects the analysis of discourse, Foucault (1978, p. 11) explains how he 'substitutes the analysis of different types of transformation for the abstract, general, and monotonous form of "change" in which one so willingly thinks in terms of succession'. In this, he seeks to define with the greatest care the transformations which have constituted the change, replacing the general theme of becoming ('general form, abstract element, primary cause, and universal effect') by the analysis of the transformations in their specificity, an examination of 'the diversity of systems and the play of discontinuities into the history of discourse' (1978, p. 15). This involves, says Foucault (1978, pp. 11-12), within a given discursive formation, (1) detecting the changes which affect the operations, objects, theoretical choices, etc.; (2) detecting the changes which affect the discursive formations themselves (e.g. changes in the boundaries that define the field); and (3) changes which affect simultaneously several discursive formations (e.g. reversal of the hierarchy of importance, as happened, for instance, in the Classical period when the analysis of language lost the 'directing role' that it had in the first years of the nineteenth century to biology, which in turn led to the development of new concepts such as 'organism', 'function', organisation', etc., which in turn affected other sciences). All of these types of changes, says Foucault, characterise changes to both individual discourses and effect modifications in the episteme itself: its 'redistributions', i.e. 'the different transformations which it is possible to describe concerning ... states of a discourse'.

In opposition to totalising models Foucault sees his own analysis as more limited: to searching for the empirical historical grounds for discursive consistency or coherence; to recognising in discourse its empirical worldly features - 'the work of the author. And why not? - His juvenilia or mature work, the patterns of a linguistic or rhetorical model (an idea, a theme)'; and acknowledging that the transformatory operations are all carried out 'prior to discourse and outside of it' (1978, p. 17).

In his later reflections on method, in response to interviews on the subject of Discipline and Punish, Foucault (1987) asserts the 'pluralist' nature of his project through his use of concepts like 'eventalization'; that 'specific events' (événements signuliers) cannot be integrated or decoded simply 
as an application of a uniform and universal regularity. In this non-unified sense, the analytic of discourse effects a non-unified method. As Foucault (1972, p. 8) explains it:

It has led to the individualization of different series, which are juxtaposed to one another, follow one another, overlap and intersect, without one being able to reduce them to a linear schema. Thus, in place of the continuous chronology of reason, which was invariably traced back to some inaccessible origin, there have appeared scales that are sometimes very brief, distinct from one another, irreducible to a single law, scales that bear a type of history peculiar to each one, and which cannot be reduced to the general model of a consciousness that acquires, progresses, and remembers.

The notion of 'eventalization' itself contains a number of elements. First, it treats all objects of knowledge as historical events. Second, it refers to a 'pluralization of causes' (Foucault, 1987, pp. 104-105):

Causal multiplication consists in analysing an event according to the multiple processes that constitute it ... 'E]ventalization' thus works by constructing around the singular event analysed as process a 'polygon' or rather a 'polyhedron' of intelligibility, the number of whose faces is not given in advance and can never properly be taken as finite. One has to proceed by progressive, necessarily incomplete saturation. And one has to bear in mind that the further one decomposes the processes under analysis, the more one is enabled, and indeed obliged to construct their external relations of intelligibility.

In addition, says Foucault (1987, p. 104) eventalization refers to the rediscovery of the 'connections, encounters, blockages, plays of forces, strategies, etc. that at a given moment establish what consequently comes to count as being self evident, universal and necessary'. In this sense, it constitutes a 'breach of self evidence', i.e.:

it means making visible a singularity at places where there is a temptation to invoke historical constants, an immediate anthropological trait, or an obviousness that imposes itself uniformly on all. To show that things 'weren't as necessary as all that'; that it wasn't a matter of course that mad people came to be regarded as mentally ill; it wasn't self-evident that the only things to be done to a criminal were to lock him up, it wasn't self-evident that the causes of illness were to be sought through the individual examination of bodies; and so on.

In this sense, eventalization opposes the evidences upon which knowledge sequences and practices rest. Its theoretical quest is endlessly open. It operates, in Foucault's (1987, p. 105) view, 'as a procedure for lightening the weight of causality'.

Alongside the concept of singular events are those of exteriority/interiority, which Foucault (1972, pp. 120-122, 125, 140) discusses in The Archaeology of Knowledge as well as in his inaugural lecture at the College de France (see Foucault, 1981), and in his essay on Blanchot (Foucault, 1990). What Foucault means by 'exteriority' is that the being of discourse resides in the 'pure dispersion' of the socio-historical processes of reproduction and change; in the particular events, regularities, relationships, modifications and systematic transformations', which constitute an 'autonomous (although dependent)' domain, and 'which can be described at its own level' (1972, pp. 121-122). As expressed in his essay on Blanchot (1990, p. 15), it is 'the breakthrough to a language from which the subject is excluded ... the being of language only appears for itself with the disappearance of the subject'. This places the emphasis on 'speech' rather than on the Cartesian Cogito. As he states (1990, p. 13):

'I speak' runs counter to 'I think'. 'I think' led to the indubitable certainty of the 'I' and its existence; 'I speak', on the other hand, distances, disperses, effaces that existence and lets only its empty emplacement appear. Thought about thought, an entire tradition wider than philosophy, has taught us that thought leads us to the deepest interiority. Speech about speech leads us, by way of literature as well as perhaps by other paths, to the outside in which the speaking subject disappears. No doubt that is why Western thought took so long to think the being of language: as if it had a premonition of the danger that the naked experience of language poses for the self-evidence of the 'I think'. 
Manfred Frank emphasises the ontological and methodological functions of exteriority. What Foucault means by exteriority, he says $(1992$, p. 108) is that each individual element in discourse is irreducible 'to the unified discursive principle, or to an internal core of meaning to be found in the discourse'. As he continues:

What the rule of exteriority of discourse means then, is: 'not moving from the discourse towards its internal, hidden core, towards the heart of the thought or the meaning, which is manifest in it'. So the procedure of the analytic of discourse is external because it wishes to leave the series (série) of single events, mutually irreducible (in terms of a deductive or teleological principle), just as they are 'external' to any totalizing general concept.

In a methodological sense, in that events and instances are individualised, 'individualised' means here, as Frank (1992, p. 110) states it, 'not predictable from the point of view of their structure, and contingent with respect to the way they happen to be'. What is important in terms of the analytics of discourse is not seeking such a reduction: hence the analytics of discourse is external to the process of analysis. What is important to Foucault (1990, pp. 15-16) is that:

thought stands outside subjectivity, setting its limits as though from without, articulating its end, making is dispersion shine forth, taking only its invincible absence; and that at the same time stands at the threshold of all positivity, not in order to grasp its foundation or justification but in order to regain the space of its unfolding, the void serving as its site, the distance in which it is constituted and into which its immediate certainties slip the moment they are glimpsed - a thought that, in relation to the interiority of our philosophical reflection and the positivity of our knowledge, constitutes what in a word we might call 'the thought from the outside'.

As well as referring to consciousness, interiority thus refers also to any foundation or centre to the social formation which the events or parts echo or reflect. Hence, again, this can also be seen as consistent with, and expressing, his opposition to the notion of a determined causality embodied in the Hegelian conception of an 'expressive totality' and, by derivation, also embodied in the notion of a primary causal necessity (un causalisme primaire) which he sees as central to Marxism. In this sense, the analytics of discourse must resist interiorisation, 'forsaking the wordy interiority of consciousness', as well appeal to a centre or foundation, and become, as in Bataille, the 'discourse of the limit' (1990, p. 18).

What Foucault, following Nietzsche, Blanchot and Bataille, also elaborates as a theme is the 'uniqueness' and 'unpredictability' of the singular historical instance, however. What he seeks to do is introduce conceptions of indeterminacy, irregularity, openness, complexity and uniqueness as integral to his conception of the historical process. In The Archaeology of Knowledge (1972, p. 101) examples abound: it takes the form of establishing the spatio-temporal coordinates that ensure the novel aspect of the 'statement' (énoncé): 'The enunciation is an unrepeatable event; it has situated and dated uniqueness that is irreducible. Yet this uniqueness allows of a number of constants grammatical, semantic, logical - by which we can, by neutralising the moment of enunciation and the co-ordinates that individuate it, recognise the general form'. Or again (1972, pp. 146-147), 'every statement belongs to a certain regularity - that consequently none can be regarded as pure creation, as the marvellous disorder of genius. But we have also seen that no statement can be regarded as inactive, and be valid as the scarcely real shadow or transfer of the initial statement. The whole enunciative field is both regular and alerted: it never sleeps'. This fact that the future never simply reproduces the past, but adds always elements of novelty, means that the self is never simply the reproduced habitus of its socialisation, but due to its necessarily distinct location in time and space and culture, as well as its progressively growing capacity for agency, is characterised by elements of difference and uniqueness. Similarly, it means that ethical values can never simply be expressed merely as repeatable rules of conduct, which increases, rather than decreases, our sense of ethical responsibility in action.

Such a conception also expresses an 'internalist' view of history. There is no guiding principle underlying structures or their emergence. Difference, then, is historical, and resists transcendence in all its forms, whether God, Cogito, Forms, Economy. There is nothing outside of history. Although such a conception does not adopt a uniform ahistorical model of temporalisation, or prioritise one element (economy) over others, neither does it deny that invariant necessities may 
exist which can express themselves through the different discursive lens of a particular historical periods. In this sense, as Joseph Margolis (1993, p. 204) notes, Foucault does not deny a world of 'things', he:

does not dismiss de re necessities of this or that episteme; they are rightly recognised there as the necessities they are. But they are also not enshrined as universal, changeless structures of any kind (regarding world or reason). [Rather] we are always invited to 'test' for the 'limits' that we may go beyond. That's to say: the invariances of any proposed transcendental limits of reason may be tested by exploring whether we can alter such a model of coherence convincingly, in a way that rests on historical change.

Similarly, such a conception can be claimed to resist the charge of epistemological relativism. As Foucault (1984b, p. 335) puts it in the Preface to the History of Sexuality, Volume II, he says that he is not denying the possibility of universal structures:

Singular forms of experience may perfectly well harbor universal structures: they may well not be independent from the concrete determination of social existence ... ( $t$ )his thought has a historicity which is proper to it. That it should have this historicity does not mean that it is deprived of all universal form but instead the putting into play of these universal forms is itself historical.

Like Heidegger, in Being and Time, Foucault manifests a pragmatic anti-foundationalism. Such an approach bears a similarity to parallel developments in Western Anglo-American philosophy to writers like Dewey, Quine, Davidson, Putnam, Kuhn and Goodman, and in the continental tradition to writers like Habermas, Bourdieu and Apel. While all developed versions of historicism, all denied any total pernicious form of relativism and all claimed a measure of objectivity. For Foucault, the maxim that 'everything is historical' means that while we remain forever imprisoned by contingency, non-correspondence, relativity and ideological prejudice, there are some 'footholds', even if they do not lead easily to a uniform consensus. Foucault's anti-essentialism places him alongside a possible (pragmatic) reading of Popper, who also rejected essentialist ontologies, in that there is nothing that prevents testing and attempted falsifications in order to 'take a bearing', or 'check the situation out'. While this will give a certain form of confidence on some issues, on others, the conditions of what constitutes falsifiability will not be so easy to foresee.[3] Foucault's realism holds to the view that correspondence or synchronisation of discourse and reality is not required. Rather than correspondence, we must speak of isomorphism. There is no assurance, pace Kant, either, of transcendentally valid and universally reliable cognitive schemata, for such a conception relies on a conception of a subject posited prior to history. What justified Kant's cognitive schemata depends on various historically contingent conditions within what Heidegger would call the 'horizon' within which they appear. This doesn't mean there are no historical justifications (survival), nor does it mean there are no footholds of any sort. But with Heidegger, Foucault's thesis of the historicity of existence would deny that there is any eternal 'point of view'.

Although Foucault acknowledges a debt to Nietzsche, it would be an error to represent his approach as simply Nietzschean, and would misrepresent his relation to Marx and to radical politics. As well as Nietzsche, Foucault has debts to Heidegger, and Herbert Dreyfus (1992, pp. 80-81) claims that 'it was through Heidegger that Foucault came to appreciate Nietzsche'. As Foucault (1985, p. 9) says, 'it is possible that if I had not read Heidegger, I would not have read Nietzsche. I had tried to read Nietzsche in the fifties but Nietzsche alone did not appeal to me whereas Nietzsche and Heidegger, that was a philosophical shock'. One of the central themes which Foucault shared with Heidegger and Nietzsche, as well as with the French Marxist, Althusser, was their challenge to the Cartesian and Kantian conceptions of the subject. He was also influenced by Heidegger in terms of the understanding of Being as indicating the presuppositions, things, tools, language, institutions, shared understandings, and other people, which determines what is deemed possible or impossible, or what counts as important or unimportant, or meaningful or unmeaningful. Like Heidegger, Foucault came to reject the view of a constant, ahistorical, universal truth, which came to influence his rejection of essentialism and other forms of foundationalism, thereby influencing the precise nature of his materialism. Yet another writer that Foucault has cause to refer to is Spinoza, whom he refers to and summarises in several of his papers 
over the course of his writing career.[4] While Spinoza cannot be represented as a direct influence, his detailed understanding of Spinoza is suggestive in that Spinoza's concepts of conatus, the univocity of being, power, politics, constitutive praxis, and the general fit with a theory of republican constitutionalism can, if suitably modified according to the dictates of difference, be rendered broadly compatible with Foucault's approach.

\section{Complexity and Openness}

In that Foucault talks of 'chance' and 'unpredictability', such a conception of historical openness is not technically incompatible with deterministic Newtonian physics, in the sense that events and outcomes are still the result of antecedent conditions. Causation, in Foucault's view, however, is conceived of systemically, in terms of a model of holism-particularism, or complex causation, which makes events, which are the outcomes of system interactions in open systems, effectively unpredictable, in that the full range of possible combinations or effects cannot be specified in advance. Complex systems, moreover, are contingent and dynamic, whereby the structure of the system is continuously transformed through the interaction of the elements and which are not explainable in reference to any external principle, origin, or foundation. In this process, says Cilliers (1998, pp. 107-108), 'no complex system, whether biological or social, can be understood without considering its history ... . To be more precise, the history of a system ... co-determines the structure of a system'. In this theory, while change is understood as the outcome of contingent complex activity, human agency is understood as an emergent property of the historical and social system.[5]

In insisting on the open nature of the historical system, Foucault's approach to understanding history parallels Derrida's critique and revision of Saussure's in stressing the open and incomplete character of the totality of social relations. In Foucault, however, the analysis proceeds beyond the textual to an analysis of the historical relations between the discursive and pre-discursive, whereas for Derrida and Saussure the analysis is synchronic and confined to language. Throughout his career, in fact, it can be said that Foucault maintains a distinction between the discursive and the pre-discursive. In his early period, prior to the Archaeology of Knowledge, written in 1968, Foucault sees discourses formed on the basis of epistemes, that provide a unified view of intellectual life during a particular period or age. After his turn to genealogy, he developed such an approach more directly in relation to how the practices discursive and pre-discursive were related. As a consequence, in retaining the post-structural emphasis on the open and incomplete nature of the totality, but applied to history and social relations, rather than language, Foucault's more materialist approach has radical implications for our understanding of concepts like determinism, predictability, and the future.

In this context, it is worth noting the parallel between Foucault's systemic conception of change, linked closely to a system of open possibilities or variations, and what is now known as complexity theory. Although having roots in ancient Chinese and Greek thought, versions of complexity theory are a relatively new field of scientific enquiry, and are perhaps one of the most notable new developments since the advent of quantum theory in the early 1900s. Such theories are not only compatible with materialism, but are systemic, or holist, in that they account for diversity and unity in the context of a systemic field of complex interactional changes. Chaos theory is one version of complexity. Partly with origins in computing technology, and partly in the development of new non-Euclidean structures of fractal geometrical mathematics, chaos theory became concerned to explain 'the qualitative study of unstable aperiodic behaviour in deterministic non-linear dynamical systems' (Sardar \& Abrams, 1999, p. 9).[6] It is complexity theory more broadly, however, that has drawn off post-structural methods, and establishes them as a form of critical realism.[7]

In his book Complexity and Postmodernism, Paul Cilliers (1998, p. viii) defines complexity in the following way:

In a complex system ... the interaction constituents of the system, and the interaction

between the system and its environment, are of such a nature that the system as a whole cannot be fully understood simply by analysing its components. Moreover, these

relationships are not fixed, but shift and change, often as a result of self-organisation. This 
can result in novel features, usually referred to in terms of emergent properties. The brain, natural language and social systems are complex.

Post-structuralism, says Cilliers, has introduced a new conception of complexity based on 'distributed' or 'relational' representation, following Saussure.[8] Such a system is complex in relation to the fact that it has a large number of elements which interact dynamically in a non-linear and asymmetrical manner. Interactions take place in open systems through 'self-organisation' by adapting dynamically to changes in both the environment and the system. Self-organisation is an emergent property of the system as a whole. An emergent property is a property that is constituted due to the combination of elements in the system as a whole. As such, it is a property possessed by the system but not by its components.[9] Cilliers (1998, p. 90) defines 'self-organisation' as 'the capacity of complex systems which enables them to develop or change internal structure spontaneously and adaptively in order to cope with or manipulate the environment'. Such systems are not in equilibrium because they are constantly changing as a consequence of interaction between system and environment, and as well as being influenced by external factors are influenced by the history of the system (1998, p. 66). Cilliers identifies social systems, the economy, the human brain, and language as complex systems.[10]

Hence one could characterise Foucault's conception of societies as 'non-equilibrium systems', where no general laws can predict the detailed behaviour of such systems. As much that develops does so as a consequence of emergence, life is created as a consequence of the collective interactions of parts. This entails not only the limitless possibility of combinations that can occur in open environments, but also that as the collectivity possesses properties and energies not possessed by the parts, but through which change can take place, new forms and patterns can develop. Relatively small changes in initial conditions can trigger major changes throughout the system, in part or whole. Such a perspective gives a new insight to the 'conrtradictions of capitalism'.[11] Although for Foucault, the economy can not be represented as a transhistorical foundation permitting an understanding of change in history, it can be analysed internally, i.e. a genealogy of capitalism in terms of the history of economic structures, and the effects they engender throughout the social structure. Although I realise that this brief account cannot possibly do justice to the topics of complexity theory, emergence, chance or critical realism, it is broadly in this direction that Foucault's historical materialism leads.

\section{The Nature of Identity}

Given that structural linguistics seeks to define identity relationally, Saussure (1974, p. 120) argued that it can not posit a theory of identity as a substantive entity, or as a concrete 'positive' unique particularity. This was retained by Derrida in his revision of Saussure's view, seeing identities as constituted by the series of traces of the differences in the system.[12] But if one conceives of identity in purely relational terms, as Mark Currie (2004, p. 13) notes, 'it could be said that the concept of difference is no respecter of difference'. As he continues, in explaining Saussure's view:

A theory of subjectivity, or personhood, for example, might locate identity not in the body of the individual but in the relations between that person and others. In other words a person might not be defined by inherent characteristics, but like Saussure's train or chess piece, be understood as an identity only because of the relationships that person has with other people, in a system of family, friendship and social relations. This would be referred to as a relational view of personal identity. The same might be said of collective identities. It might be argued for example, that a national identity is not one that is made up of inherent qualities (of 'positive terms' in Saussure's language) but of relational ones concerned with how a nation distinguishes itself from other nations.

For Nietzsche, Deleuze and Foucault, difference operates historically and has a dynamic quality that the theories of Saussure and Derrida lack. On this basis there is no reason why the traces that infuse identity could not be seen as leaving a residue or mark, developing into a positive conception of self constituted through complex interactions in the to and from of the historical process. The stress on historical praxis creates a more enduring sense of identity in this sense. While this still leaves identity as relational in terms of its constitution, an identity which can be 
represented as positive and substantial (in the sense of it being irrepressible or non-reducible) is the outcome of self-creation or constitutive praxis in history.[13]

Such a view has the advantage over Saussure's and Derrida's view in that it can account for a substantial conception of the self, and explain, in the context of historical and social contructionist views of the self, how identities can emerge that are both distinct and unique [14], which are nonreversible, and irreducible to the social whole.[15] For Nietzsche and Deleuze, following Duns Scotus, Spinoza and Hume, identities are constituted in experience, which is defined in terms of complex effects and relations, as practices (or for Deleuze, haecceities) whose complex modes of operation are individuating (but not personalising or privatising). For Deleuze (1985, Deleuze \& Guattari, 1987, ch. 1), such patterns show parallels to nomadology or rhizomatic (rather than arborescent) development. For Foucault (1990), it is 'outside thought'; for Nietzsche, 'gay science'. In twentieth-century Marxist thought, Althusser's conception of structural causality, as outlined at the start of this article, partly fits such a model.[16] Similar models of organisation and development are also evident in Spinoza's 'ethics', as what Spinozian interpreters like Damasio (2003, p. 37) call 'nesting' theories of development, where the 'parts of simple reactions [are] incorporated as components of more elaborate ones, a nesting of the simple within the complex'.[17] Yet other approaches utilising complex models, although in somewhat variable ways, are cybernetics, or the early theories of Gregory Bateson (see Bateson, 1972)

\section{Difference and Community}

That Foucault identifies pluralism as a central principle on which Marxism fails has affinities with liberal criticisms of Marxism and Hegelianism. Foucault's opposition to utopianism and his unease regarding consensus models of policy making parallel liberal sentiments as well. Yet to what extent this represents a failure to face up to the issue of collective politics might well be asked. Given also a marked reluctance to theorise the role of the state, one could ask whether Foucault doesn't implicitly fall back on some conception of the invisible hand of a beneficent nature with respect to the coordinative tasks of human collectivities.

If his conception of difference is not to merely result in an atomistic retreat to individualism, it must within it, or in relation to it, build in a notion of community. Because this is not normally the way Foucault or post-structuralist conceptions are stated, it is necessary to further articulate the justifications for such a designation. Central to my argument is that Foucault's notion of difference presupposes a 'minimal universalism', which in turn necessitates a certain conception of community. Just as people are marked by their difference, they also have commonalities between them. While aspects of race or culture may separate them, they will be linked in their common aspirations (food, shelter and support). To say this is to say that difference must be paired with commonality in a way where neither is reducible to the other. As Deleuze might say, while any structures manifest segmentarity, the point that also needs to be made is that proliferating segmentarities are also characterised by structure.

My own way of representing this is to say that that differences must be underpinned by a minimal universalism. By this I mean a limited and conditional universalism which does not 'overarch' or 'ground' difference, but which must be seen as always 'co-present' with difference, and which permits of variations in degree in different times and places. It is not a Kantian universalism in relation to reason but rather a Nietzschean and Spinozian universalism conditional upon the will of the human species to survive. To the extent that there is such a will to survive, then there are certain implications for democratic politics and the equalisation of power, and certain shared concerns. The argument is that a concordance of difference and unity is a requirement of Foucault's thought if it is not to suffer from self-contradiction. While Foucault supports a conception of the politics and philosophy of difference in the sense that he opposes the unitaristic tendencies inherent in Hegelianism, Marxism, and other Enlightenment discourses as well, it is important that he does not privilege difference over unity, or to the exclusion of unity.

This perspective, which entails that difference can only be articulated in the context of a concept of community, stands opposed to the perspective of some post-structuralist writers. My own argument places greater emphasis upon the complementary nature of difference and community. It is based both on an analysis of the concept of difference in Western philosophical ontology and on 
Foucault's representation of difference as dialogical or relational, presupposing strategies to equalise power relations, involving, not isolation or separateness, but an open-ended process of negotiation and debate.

Since the time of the Greeks, and certainly in Marxism and Hegelianism, difference has been articulated in relation to unity. While Marxism has always refused to make the theme of difference its organising principle, it has always found a place for difference in relation to unity. What the post-structuralist correction involves, then, is altering their ontological weightings of 'unity' and 'difference' within the context of the theory as a whole. As Milton Fisk (1993, p. 326) observes:

The materialist interpretation of history is certainly in the tradition of the theme of difference-in-unity, for it attempts to organise the different aspects of a society around its economy considered as a unity ... Post Marxists of the poststructuralist sort claim that privileging gets us into difficulty since it is inherently reductionist of differences.

The central argument here - that Foucault must be adjudged a 'thin' communitarian - relates to the sub-arguments that difference cannot constitute a structuring ontological principle on its own, but must always be seen in relation to unity. While difference will affect the sort of communitarianism that Foucault could be adjudged as subscribing to, it nevertheless constitutes the ordering principle of a community. The central point here is that, as Fisk (1993) observes, the ontological postulates of difference and unity have to be kept in balance, which is to say that the principle of difference cannot plausibly explain social relations on its own (Fisk, 1993, p. 324). This is why in classical philosophy the theme of otherness, which underpins difference, was always paired with that of unity or identity. To try to make one's philosophical orientation work solely on the grounds of difference neglects equally strong arguments for 'unity'. For to try to define objects solely in terms of differences neglects equally compelling reasons for considering them as objects of certain kinds. Similarly, if, as the post-structuralist insists, a final synthesis is not possible to achieve, this doesn't mean, nor should it entail, that all unities or identities simply collapse into differences, or that social life is simply a process of endless, vicious regress. In short, as Fisk (1993, p. 325) argues, unless the theory of difference is to result in incoherence, there must be a minimal kind of unity. This is perhaps the major reason for considering Foucault as a 'thin' communitarian.

To represent this argument in political terms, it can be said that pushing the principle of difference too far results in contradiction. While Foucault, like Deleuze, wants to celebrate multiplicity and a decentred polis, the fundamental ambiguity results from the fact that respecting the autonomy of different groups - whether based on religion, race, gender, or ethnicity - is only possible within certain bounds unless difference is to be elevated as a new universal. This paradoxically lets Kant in through the back door: 'act always so as to respect the difference of the other'.

Todd May (1994, pp. 39-40) develops a similar argument in relation to Deleuze, which applies equally well to Foucault. As he expresses the point:

Thus Deleuze asks us to think difference as constitutive all the way, and of unity as a product of the play of difference. But if difference is to be thought of as constitutive, this is in order to rid philosophy not of unities, but of unifying forces or principles that either preclude difference or relegate it to a negative phenomenon.

Part of the point here is that difference cannot be reduced to a logic outside of history or injected with metaphysical serum. Thus, for Foucault, neither difference nor unity can be seen as primary. As May (1994, pp. 46-47) puts the point:

If meaning were merely the product of difference, there would be no meaning, only noises unrelated to each other. In order for meaning to occur, identity must exist within difference, or better, each must exist within the other. To speak with Saussure, if language is a system of differences, it is not only differences but system as well; and system carries with it the thought of identity ... to posit a concept whose function is to be given primacy to difference is to violate the necessary chiasmic relationship between unity and difference.

Like Deleuze, Foucault utilizes difference to create a context to shape a way of thinking for a general perspective. Central here is how the concept of difference is to function, and for Foucault the principle functions to undermine the unity of being that has reigned supreme from Plato to 
Hegel, to introduce a new way of thinking philosophically. Yet difference and commonality exist in relation to each other: in that people all manifest the commonality of needing nutrition, they manifest difference in relation to that single goal. In Foucault's pluralism, systems are not unities but compositions of series, each defined on the basis of difference.

In this sense, it is necessary to modify post-structuralist thought in several senses, for difference cannot explain identity on its own. It cannot explain diversity either, for if all were simply different there would be unintelligible communities who could not relate to each other. In this sense, as Philip Pettit (1997, p. 249) explains with respect to the 'politics of difference':

that while it requires partial forms of civility in order to be effective, it also requires a disposition on the part of people, even people of quite different perspectives, to display a civility that relates to the society as a whole. Let people cease to countenance society-wide norms in their enthusiasm for more local affiliations, and the republic will degenerate into a battlefield of rival interest fields.

Thus, while we may accept Deleuze's and Foucault's Spinozist position seeing difference as constitutive of reality, but seeing unities and commonalities as the contingent outcome (assemblages, apparatuses, hegemonies), or in Spinoza's sense, as the 'expression' of historical practice, pluralism cannot be seen as founded on a metaphysical atomism but must be seen as describing a world of interconnections and relations linked to the inevitability of commonalities, or of totalising episodes. What should thus be noted with respect to Deleuze and Foucault is that neither necessarily sees difference as metaphysically detached from commonalities/unities, or as one set being reducible to the other.

It is also important to distinguish 'unity' from 'commonality', however. To say that communities must have common features is not to say they need be highly unified or consensual. A community may have commonality (of concerns, interests, features) without having an excessively high degree of unity, or even without having a centre, hence giving rise to the possibility of an acentred community.[18] In addition to this, we may also characterise communities as varying in their degree of unity, i.e. as displaying different relations of unity/difference at different historical periods. In terms of historical practice, in particular societies at particular times, we might also distinguish processes of convergence (or what Foucault called totalization) as opposed to processes of deconvergence (individualization). Processes of decovergence allow for greater difference, whereas processes of convergence stress unity. Nazism represents a supreme example of convergence in the recent normative history of states. Some societies may encourage unity, or uniformity, however, if the overall tasks of survival and well-being are being threatened.[19]

The political problem, not adequately addressed by either Marx or Foucault, is one of reconciling the collective with the particular. If Hegel's theism defines the limits at which unity is imposed, then the permissibility of difference (diversity) will be very confined, and Hegel has been rightly criticised on this ground.[20] If the limits on diversity are in accord with species survival and well-being, however, given optimal historical circumstances, they may be much wider, as this is a broad criterion potentially permitting of a wide range of styles of life.[21] At a social ontological level, these are always in tension, and are historically variable, in terms of society's or humanity's relation to survival and well-being. At a political/normative level, as Marx suggestively pointed out in his critique of Hegel, they are tensions which only democracy can reconcile.[22] And clearly it is appropriate that difference is an entitlement to the extent that the survival (of individuals, groups, and humanity) is not threatened.

\section{Conclusion}

While Foucault's project thus marks a break with Marxism's central postulates, there is, as Balibar (1992, p. 56) observes, a partial usage of Marxist tenets as well. Like Marx, Foucault asks questions of the same order, concerning philosophy and philosophy of history, and concerning the nature of historical investigations. Both writers can be represented as 'historical materialists', albeit, in quite different senses. As Balibar (1992, pp. 54-55) notes:

Inasmuch as it is true that the shift in philosophy as practised by Marx and by Foucault involves, in a nutshell, the need which has existed for a century to move from a philosophy 
of history to a philosophy in history, it is necessary, in the rigorous form of a series of dilemmas (either Marx or Foucault), that the main lines of tension of a theoretical field should become apparent and, eventually, definable. This field must, in some form, already exist, and it must already have been traversed and particularised. Nonetheless it must remain to a large extent to be discovered and defined cartographically. Perhaps it could be referred to as the field of 'historical materialism' ... . Central to this ... is the concept of social relations or contradictions as a structure internal to power relations. This is what sustains the Marxian notion of historical materialism. This then is what, more and more explicitly, Foucault questions. At the (provisional) point of his evolution on this question ... he developed ideas which it would not be wrong to refer to by the name of 'historical materialism', but in a way which is opposed, in each of the ways in which it is meant, to Marx: materiality is seen not as the materiality of 'social relations' but as the materiality of the apparatus and practice of power, inasmuch as it affects bodies; historicity is seen not as the historicity of contradiction (whether this be viewed as an instance of the totalisation of different forms of struggle or as an instance of the interiorisation of their necessity) but in terms of the historicity of the event; the improbable outcome of various strategies of repression and of multiple and partially uncontrollable forms of subjugation.

Balibar's point that Foucault addresses the issue in a way that is 'opposed' to Marx needs some qualification, however. Although Foucault does focus on power relations generally, rather than privilege productive economic relations specifically, his approach is still compatible with a materiality of social relations in this broader sense, as well as with a thesis of the 'univocity of being' of material physical necessities of the world. In relation to historicity, moreover, while he does reject the notion of the dialectic, in preference for an ontology based on events and practices, his approach still implies the historicity and relativity of all established structures and orders, political, economic and theoretical, and of social systems, institutions and concepts.

His approach can be seen as representing, then, a complex relation to Marx. While Foucault clearly rejects the Feuerbachian humanist emphasis of the early Marx, which sees men as realising their essence in history, as they throw off the conditions of their repression and alienation, Foucault's anti-essentialism would signal a rejection of teleology, in that, for him, there is no essence to be liberated. For Foucault, development is not conceived as an unfolding, or unwinding, or recovery of one's true humanity, but as an act of individual and collective self-constitution.

Such a view is not, of course, necessarily in conflict with the more materialistic position of the later Marx, once he had recanted the Feuerbachian humanist emphasis of the earlier period. Indeed, in many respects, Foucault's theoretical anti-humanism accords with Althusser's (1969, 1970) interpretation of Marx's position, after the 'epistemological break' of 1845. Certainly, in The Holy Family, written in Paris in the autumn of 1844, Marx reveals a new more materialist, less humanist, less idealist perspective, and repudiates the humanist metaphysical and contemplative materialism of his earlier Thesis on Feuerbach. It squares, too, with Engels's (1956, p. 11) description of The Holy Family when he wrote:

The cult of abstract man, which formed the kernel of Feuerbach's new religion, had to be replaced by the science of real men and of their historical development. This fuller development of Feuerbach's standpoint beyond Feuerbach was inaugurated by Marx in 1845 in The Holy Family.

Such a perspective leads Foucault to represent history, as Althusser represents Marx's view: not as a teleology, but as 'process without a subject' (see Althusser, 1969, 1970, 1982, p. 183). Yet, while the affinities are clearly there, unlike Althusser, Foucault seeks also to overcome the problems of structuralism, which posited a single founding structure as the basis of explaining the nature of experience.[23] Structuralism also fails to account for agency in history, or for any conception of the constitution of the identity of the self in history.[24] Foucault's more historical and more nominalist approach led him to express a fundamental optimism over the prospects for selfcreation, emphasising the creative role of the human will within the historical process. This gives a specifically critical role for the intellectual and educator. As he states (Martin et al, 1988, p. 10):

My role ... is to show people that they are much freer than they feel, that people accept as truth, as evidence, some themes which have been built up at a certain moment during 
history, and that this so-called evidence can be criticised and destroyed. To change

something in the minds of people - that is the role of the intellectual.

This also gives a role to critique, and transcendence which, within the context of history and its contingencies seek to expose the historical transitory constraints of contemporary consciousness as realised in and through discursive practices. Such constraints impose limitations which have become so intimately a part of the way that people experience their lives that they no longer experience these systems as limitations but embrace them as the very structure of normal and natural human behaviour. Within these limits, seen as both the limits of reason and the limits of nature, freedom is subordinated to reason, which is subordinated to nature, and it is against such a reduction of reason to nature that Foucault struggles. His commitment is to a form of 'permanent criticism' which must be seen as linked to his broader programme of freedom of thought. It is the freedom to think differently than what we already know.

Notwithstanding his opposition to Hegel, consensus politics, and utopian reasoning, with Foucault, as with Marx, the historical and social achieve an ontological status, which are to be understood, more through individual and collective practices of trial and error, than through any appeal to the senses or the autonomy of reason. It is the practices of history and society that write the script on the body, and which constitute identity. This was an emphasis which made him depart from the linguistic turn in French thought.

Foucault sees Marx as writing squarely within an Enlightenment problematic, and as overemphasising the importance of rationality of the human subject, as well as human agency in both individual and collective terms. While reason is not impossible, it is not autonomous or independent of prevailing social and historical conditions, nor is it simply a pure expression of the prevailing socialised patterns of the class system, nor manifested solely in relation to the individual or the group. Reason is possible, but individuals' rational faculties are both clouded and impeded by prevailing ideologies, by oppressive social conditions, or by inadequate education of critical faculties and capabilities. Exercising rational capacity depends upon these prior resources and development; it depends on effective collective structures of education, deliberation, communication and dialogue. It depends too on the existence of democratic structures so that policies can be developed, discussed, framed and implemented.

As with Spinoza and Marx, for Foucault the fortunes of the individual are linked to those of the collective. It was in challenging domination, where the forces of power are unequal, not just in the economy, but as they echo throughout the entire social formation. If power operates everywhere, then it is in exposing the way it secretes itself in the fine textures of societies, and in how it manifests itself, unrecognised, in the operations of people's lives, that becomes of crucial concern. For Foucault, Nietzsche recovers Marx's original intention, in that while not neglecting economic power, he extends our understanding of it as something overdetermined and called forth in the processes, strategies and mechanisms by which reproduction and change are affected. As exemplified by what is rejected in deterministic and economistic versions of Marx, based on dialectical logics, the priorities of the economy, and historical teleologies, Foucault advances a conception of struggle, force and strategy; and rather than invariant ahistorical categories of class and economy, history is viewed as based on contingency and a conception of complex causality and chance. In this scenario, criticism is about identifying and removing constraints. As Foucault (1984c, p. 45) puts it in opposition to Kant:

Criticism indeed consists of analysing and reflecting upon limits. But if the Kantian question was that of knowing what limits knowledge must abstain from transgressing it seems to me that the critical question today has to be turned back into a positive one: in what is given to us as universal, necessary or obligatory, what part is taken up by things which are actually singular, contingent, the product of arbitrary constraints? The point, in brief, is to transform critique conducted in the form of necessary limitations into a practical critique that takes the form of a possible transgression.

If for Foucault transcendence does not posit linear succession to a new tomorrow, or posit solutions in a utopia of objectively ordered possibilities, this is because the utopian spirit, as I have argued elsewhere (Olssen, 2003), is embodied - 'repressed' - within the present, in Foucault's work. This gives us a normative politics of the present based upon openness and struggle. Class 
struggles - yes, but not just class struggles. Also, race struggles, sex and gender struggles, developmental and lifestyle struggles, struggles to throw off domination and reclaim freedom through equalising power, challenging hegemonies, and resisting servitude. Like Marx, Foucault's reluctance to 'posit solutions' left him without an articulated and developed conception of politics, which leaves an opening for future intellectual work as to how Nietzsche can supplement Marx, in the quest for a radical conception of democracy which overcomes the problems of totality and determination. In this sense, as McDonald (2002) notes perceptively, Marx's ideas represent an important 'limit-experience' within Foucault's theory.[25] This is a Marx freed from the dogma of nineteenth-century categories, perhaps best illustrated in his Preface to Anti-Oedipus, which he titled 'Introduction to the Nonfascist Life'. Here Foucault (2001, pp. 108-109) lists the following principles:

- Free political action from all unitary and totalizing paranoia.

- Develop action, thought and desires by proliferation, juxtaposition, and disjunction, and not by subdivision and pyramidal hierarchization.

- Withdraw allegiance from the old categories of the Negative (law, limit, castration, lack, lacuna), which Western thought has long held sacred as a form of power and an access to reality. Prefer what is positive and multiple, difference over uniformity, flows over unities, mobile arrangements over systems. Believe that what is productive is not sedentary but nomadic.

- Do not think that one has to be sad in order to be militant, even though the thing one is fighting is abominable. It is the connection of desire to reality ... that possesses revolutionary force.

- Do not use thought to ground a political practice in Truth, nor political action to discredit, as mere speculation, a line of thought. Use political practice as an intensifier of thought, and analysis as a multiplier of the forms and domains for the intervention of political action.

- Do not demand of politics that it restore the 'rights' of the individual, as philosophy has

defined them. The individual is the product of power. What is needed is to 'de-individualize' by means of multiplication and displacement, diverse combinations. The group must not be the organic bond uniting hierarchized individuals, but a constant generator of de-

individualization.

- Do not become enamoured of power.

Given that Foucault's theories point logically in this direction, it is surprising that he at times underemphasised the importance of collective power and the state to the extent he did. Given the ever-present dangers thrown up by the unpredictable happenings of the global environment, the coordinative role of the state, and of global agencies, would seem to be of central importance as we enter the twenty-first century. What is in an individual's interests is inseparable from the collective interest of humankind, and from the security of the planet. In an age of terrorism and climate change, the possibilities of individuals existing in a quasi-anarchistic utopia, where the problems of individuals are not coordinated collectively, is unimaginable. Rather than accept a theory of the reduced or minimal state, as Hayek and liberals do, and as Foucault was at times inclined to do, as an answer to the significant problems posed by collective power today, one must, in a global era, adopt a different strategy and ask instead, how can the state and collective power be harnessed and controlled, and how must institutional and international relations be reconfigured as a result. I have argued elsewhere for what can be called a comprehensive theory of democracy operating in the context of a global theory of institutional checks and balances, as well as within particular nation states. It is in this direction, supported by the norms of equalisation and democratisation, that a Foucauldian historical materialism of power must lead. If global society is a complex structure of conflicting powers, radical democracy would seem to be the best structure where conflict is best settled in a design for adaptive compromise in the interests of survival.

\section{Notes}

[1] I would like to thank Semiotext(e) for permission to publish this expanded quotation from Michel Foucault: remarks on Marx (Foucault, 1991b). 
[2] In his review of Deleuze's books ('Theatrum Philosophicum') Foucault (1998, p. 366) reinforces the importance of chance: 'The present as the recurrence of difference, as repetition giving voice to difference, affirms at once the totality of chance. The univocity of being in Duns Scotus led to the immobility of an abstraction, in Spinoza it led to the necessity and eternity of substance; but here it leads to the single throw of chance in the fissure of the present. If being always declares itself in the same way, it is not because being is one but because the totality of chance is affirmed in the single dice throw of the present'.

[3] As, for example, when they tried to test Copernicus's theories in astronomy by dropping stones from church spires to test to see whether the earth was rotating on its axis.

[4] See, for instance, Foucault's essay 'Truth and Juridical Forms', originally published in May 1973, where he summarises Spinoza in relation to Nietzsche (Foucault, 2001, pp. 11-12); again, Foucault refers to Spinoza in the debate with Chomsky (Foucault \& Chomsky, 1997, p. 136); in 'Theatrum Philosophicum' (Foucault, 1998, pp. 359-360 and 366-367); and in 'Afterword to The Temptation of St Anthony' (1998, p. 105), just to name a few. It is also noteworthy that Deleuze was influenced by Spinoza, as Deleuze had a strong influence on Foucault. See Paul Veyne (1997, pp. 63-64), 'Foucault Revolutionizes History’. Also see index entries to Deleuze \& Guattari (1987), Deleuze, (1990, 1994) and others. Like Deleuze, Foucault (1998, p. 364) 'adapts' Spinozist concepts to express his views. For example: 'The univocity of being, its singleness of expression, is paradoxically the principal condition that permits difference to escape the domination of identity, frees it from the law of the Same as a simple opposition within conceptual elements'.

[5] Foucault, like Nietzsche, wrote philosophically, and hence his use of terms like 'chance', 'unpredictability' possibly lacks technical translatability to the language of natural science. An account of classical definition of concepts such as 'stability', 'chance', etc. is given by Cilliers (1998). In complex systems, as Cilliers (1998, p. 109) says, 'novel, unpredicted behaviour need not be a result of chance. It can be "caused" by the complex interaction of a large number of factors ... . Complexity is not to be confused with randomness and chance, but cannot be confused with first-order logical terms either'. In this sense, we can speak of events which are theoretically unpredictable, which are not explainable in terms of 'chance'.

[6] For other accounts of chaos theory, see Swinney (1983), Holden (1985), Gleick (1987), Sappington (1990) and Ayers (1997).

[7] Chaos theory and complexity theories are distinct although chaos theory can be seen as one type of complexity theory, which emphasises the importance of sensitivity to initial conditions. This is not so important with complex systems in general, which stress the interaction of a large number of components (see Cilliers, 1998, p. ix).

[8] Meaning is conferred not by one-to-one correspondence with the world but by relationships between structural components of the system. See Cilliers (1998, p. 81). His analysis of post-structural complexity is based on Saussure's well-known analysis in the Course in General Linguistics (1974). Having said this, it is interesting that Cilliers translates post-structural philosophy into Western analytic schemas rather than elaborate his thesis in relation to difference theory as elaborated by Foucault or Deleuze. I have done the same here simply to convey something of the tenor of the poststructural innovation.

[9] Other forms of emergentist materialism in Western thought, see Bunge (1977), Haken (1977, 1990), or Skarda \& Freeman (1990). Although such theories are broadly analogous to Foucault's materialism, the emphasis in post-structuralism on the open and incomplete character of the totality presents new insights into issues like determination and chance. Again, see Cilliers (1998)

[10] For another view of complexity theory, see Kauffman (1991, 1993, 1995). Kauffman suggests that while events can be seen as having antecedent conditions which explain them, in open environments the possible combinations are unpredictable. Other characteristics of complex systems are that they do not operate near equilibrium; the relationships between components are non-linear and dynamic; elements do not have fixed positions; the relationships between elements are not stable; and there are always more possibilities than can be actualised.

[11] The notion, for example, that carbon emissions can trigger climate change, which can have potentially unpredictable effects of unimaginable severity, is one illustration of how determination works in relation to complex causality. 
Foucault and Marxism

[12] For Derrida (1981, p. 26) the sign has no positive identity but comprises only the collection of traces of all the other signs that run through it.

[13] If we think of someone like 'Churchill', there is something trite in representing him as the outcome of the play of differences (Churchill is not Balfour, not Astor, not Baldwin, etc.), for agency in history established a substantial, yet non-essential sense. Yet this identity is still always precarious, incomplete, fragmented, inconsistent, and transitional. It represents at any particular time, a 'settlement'.

[14] Liberals, especially Rawls (1971), bemoaned in A Theory of Justice that it was necessary to retreat to deontology (return to a rights discourse) because social approaches (including utilitarianism) could not account for the distinctness of identity.

[15] Such theories of complex emergentist materialism can also account for the origins of mind as irrepressible (non-reducible) yet wholly material, or physical.

[16] Such complex non-linear models are historically contingent in terms of their internal, substantive arrangements. In Althusser, the variability of the effectivity of the levels of practices of the social formation conforms to such a complex formula, albeit in structuralist and decidedly non-nominalistic terms. The ultimate necessity of the economic, however, does not conform, as it introduces a causal factor which is historically invariant across successive modes of production. In this sense, to use Deleuze \& Guattari's (1987) language, Althusser's model of structural causality conforms to both rhizonomic and arborescent forms.

[17] Damasio (2003, pp. 45-46) uses examples of social emotions, including sympathy, embarrassment, shame, etc., to exemplify the nesting principle. As he states (pp. 45-46), 'a whole retinue of regulatory reactions along with elements present in primary emotions can be identified as subcomponents of social emotions in varied combinations. The nested incorporation of components from lower tiers is apparent. Think how the social emotion 'contempt' borrows from the facial expressions of 'disgust', a primary emotion that evolved in association with the autonomous and beneficial rejection of potentially toxic foods'. The appropriate image for these reactions 'is not that of a simple linear hierarchy' (p. 38).

[18] Indeed, one might characterise the global community in such a way, but one could conceivably characterise various national communities in such a way as well.

[19] For example, they may restrict the choices available to citizens. Many African states justified not having a British-styled higher education system based on the argument that they could not afford the luxury of a liberal education which was not vocationally oriented. Such societies may restrict choices without being totalitarian.

[20] The Absolute for Hegel reconciled individual interests with the State, and ultimately, God, on the basis of a proscribed moral truth about how life should be conducted.

[21] In the West, it is on the basis that the goals of survival and well-being are achieved that liberty is secured.

[22] See Marx's 'Critique of Hegel's Philosophy of the State' first published in 1843, reprinted in Marx (1967, p. 174). Here Marx says that 'democracy, therefore, is the true unity of the general and the particular ... . In democracy there is particular human existence ... This is the basic uniqueness of democracy'.

[23] Whether Marx did ever fully expunge all essentialist aspects from his anthropology is, of course, an issue of some debate, but not one that I wish to pursue here.

[24] On Foucault and structuralism, see my article 'Structuralism, Post-structuralism, Neo-liberalism' (Olssen, 2003).

[25] The concept of 'limit-experience' Foucault drew from George Bataille. For an early discussion, see his article 'A Preface to Transgression' (Foucault, 1977a). Also see Foucault (1991b, pp. 31-32).

\section{References}

Althusser, L. (1969) For Marx, trans. Ben Brewster. Harmondsworth: Penguin.

Althusser, L. (1970) Reading Capital. London: New Left Books.

Althusser, L. (1982) Montesquieu, Rousseau, Marx: politics and history, trans. Ben Brewster. London: Verso 
Ayers, S. (1997) The Application of Chaos Theory to Psychology, Theory and Psychology, 7(3), pp. 373-398.

Balibar, E. (1992) Foucault and Marx: the question of nominalism, in T.J. Armstrong (Ed.) Michel Foucault: philosopher, pp. 38-56. New York and London: Harvester Wheatsheaf.

Barrett, M. (1988) The Politics of Truth. Cambridge: Polity Press.

Bateson, G. (1972) Steps towards an Ecology of Mind. New York: Ballantine Books.

Bunge, M (1977) Emergence and the Mind: commentary, Neuroscience, 2, pp. 501-509.

Cilliers, P. (1998) Complexity and Postmodernism. London and New York: Routledge.

Currie, M. (2004) Difference. London and New York: Routledge.

Damasio, A. (2003) Looking for Spinoza. London: Verso.

Davidson, A. (1997) Foucault and His Interlocutors. Chicago and London: University of Chicago Press.

Deleuze, G. (1985) Nomad Thought, in Donald B. Allison (Ed.) The New Nietzsche. Cambridge, MA: MIT Press.

Deleuze, G. (1990) The Logic of Sense, trans. Mark Lester with Charles Stiavale, ed. Constantin V. Bourdas. New York: Columbia University Press.

Deleuze, G. (1994) Difference and Repetition, trans. Paul Patton. London: Continuum.

Deleuze, G. \& Guattari, F. (1987) A Thousand Plateaus: capitalism and schizophrenia, trans. and Foreword by Brian Massumi. London and New York: Continuum.

Derrida, J. (1981) Positions. Chicago: University of Chicago Press.

Dreyfus, H. (1992) On the Ordering of Things: being and power in Heidegger and Foucault, in J.J. Armstrong (Ed.) Michel Foucault; philosopher, pp. 80-98. New York and London: Harvester Wheatsheaf.

Engels, F. (1956) Ludwig Feuerbach and the End of Classical German Philosophy, in K. Marx \& F. Engels The Holy Family. Moscow: Foreign Languages Publishing House.

Engels, F. (1978) Letter to Joseph Bloch, in R.C. Tucker (Ed.) The Marx-Engels Reader, 2nd edn, pp. 760-765. New York and London: W.W. Norton. (Original work published 1890.)

Fisk, M. (1993) Poststructuralism, Difference and Marxism, Praxis International, 12, pp. 323-340.

Foucault, M. (1972) The Archaeology of Knowledge, trans. A. Sheridan. London: Tavistock.

Foucault, M. (1977a) A Preface to Transgression, in D. Bouchard (Ed.) Language, Counter-Memory, Practice: selected essays and interviews, trans. D. Bouchard \& S. Simon, pp. 29-52. Ithaca: Cornell University Press.

Foucault, M. (1977b) Discipline and Punish, trans. A. Sheridan. New York: Pantheon.

Foucault, M. (1978) Politics and the Study of Discourse, trans. C. Gordon, Ideology and Consciousness, 3 (Spring), pp. 7-26.

Foucault, M. (1980a) Truth and Power, in C. Gordon (Ed.) Power/Knowledge: selected interviews and other writings 1972-1977, pp. 109-133. Brighton: Harvester Press.

Foucault, M. (1980b) Prison Talk, trans. C. Gordon, in C. Gordon (Ed.) Power/Knowledge: selected interviews and other writings, 1972-1977, pp. 37-54. Brighton: Harvester Press.

Foucault, M. (1981) The Order of Discourse, trans. Ian McLeod, in R. Young (Ed.) Untying the Text. London: Routledge \& Kegan Paul.

Foucault, M. (1984a) Politics and Ethics: an interview, trans. C. Porter, in P. Rabinow (Ed.) The Foucault Reader, pp. 373-380. New York: Pantheon.

Foucault, M (1984b) Preface to the History of Sexuality, Volume II, in P. Rabinow (Ed.) The Foucault Reader. New York: Pantheon.

Foucault, M. (1984c) What is Enlightenment? trans. C. Porter, in P. Rabinow (Ed.) The Foucault Reader, pp. 31-50. New York: Pantheon.

Foucault, M. (1985) Final Interview (trans. T. Levin \& I. Lorenz), Raritan, 5 (Summer), pp. 1-13. (Interview conducted by G. Barbedette, published in Les Louvelles, 28 June 1984.)

Foucault, M. (1987) Questions of Method, in K. Baynes, J. Bonman \& T. McCarthy (Eds) After Philosophy: end or transformation, pp. 100-117. Cambridge, MA: MIT Press.

Foucault, M. (1988) Critical Theory/Intellectual History (an interview with Michel Foucault by Gérard Raulet), in Michel Foucault Politics Philosophy Culture: interviews and other writings 1977-1984, trans. Alan Sheridan and others, ed. Lawrence D. Kritzman. New York and London: Routledge.

Foucault, M. (1990) Maurice Blanchot: the thought from outside, in Michel Foucault \& Maurice Blanchot, Foucault/Blanchot, trans. Jeffrey Mehlman \& Brian Massumi. New York: Zone Books. 
Foucault, M. (1991a) The Ethic of Care for the Self as a Practice of Freedom: an interview, trans. J.D. Gauthier, in J. Bernauer \& D. Rasmussen (Eds) The Final Foucault. Cambridge, MA: MIT Press.

Foucault, M. (1991b) Remarks on Marx: conversations with Duccio Trombadori, trans. R.J. Goldstein \& J. Cascaito. New York: Semiotext(e).

Foucault, M. (1994a) La philosophie analytique de la politique, in D. Defert \& F. Ewald (Eds) with J. Lagrange Dits et écrits: 1954-1988, 3(232), pp. 534-551. Paris: Editions Gallimard.

Foucault, M. (1994b) Linguistique et sciences sociales, in D. Defert \& F. Ewald (Eds) with J. Lagrange Dits et écrits: 1954-1988, 4 vols, 1(70), pp. 821-842. Paris: Gallimard.

Foucault, M. (1994c) Interview avec Michel Foucault, in: D. Defert \& F. Ewald (Eds) with J. Lagrange Dits et écrits: 1954-1988, 4 vols, 1, pp. 654-660. Paris: Editions Gallimard.

Foucault, M. (1998) Theatrum Philosophicum, in James D. Faubion (Ed.) Michel Foucault: aesthetics, method, and epistemology (The Essential Works, volume 2), pp. 343-368. London: Penguin.

Foucault, M. (2001) Interview with Michel Foucault, in James D. Faubion (Ed.) Michel Foucault: power (The Essential Works, volume 3), pp. 239-297. London: Penguin.

Foucault, M. \& Chomsky, N. (1997) Human Nature: justice versus power, in Arnold I. Davidson (Ed.) Foucault and his Interlocutors, pp. 107-182. Chicago and London: University of Chicago Press.

Frank, M. (1992) On Foucault's Concept of Discourse, in T.J. Armstrong (trans.) Michel Foucault: philosopher, pp. 99-117. New York: Harvester Wheatsheaf.

Gleick, J. (1987) Chaos: making a new science. London: Abacus.

Grosz, E. (1989) Sexual Subversions. Sydney: Allen \& Unwin.

Haken, H. (1977) Synergetics - an introduction. Springer Series of Synergetics, 1. Berlin: Springer.

Haken, H. (1990) Synergetics as a Tool for the Conceptualization and Mathematization of Cognition and Behaviour - How Far Can We Go? in H. Haken \& M. Stadler (Eds) Synergetics of Cognition, pp. 2-31. Berlin: Springer.

Holden, A. (1985) Chaos is No Longer a Dirty Word, New Scientist, 25 April, pp. 12-15.

Jameson, F. (1984) Foreword, in J.-F. Lyotard The Postmodern Condition. Minneapolis: University of Minnesota Press.

Kauffman, S.A. (1991) Antichaos and Adaptation, Scientific American, August, pp. 64-70.

Kauffman, S.A. (1993) The Origins of Order: self-organisation and selection in evolution. New York: Oxford University Press.

Kauffman, S.A. (1995) At Home in the Universe: the search for laws of complexity. London: Viking Press.

McDonald, B.J. (2002) Marx, Foucault, Genealogy, Polity, 34(13), pp. 259-275.

Margolis, J. (1993) The Flux of History and the Flux of Science. Berkeley: University of California Press.

Martin, L., Gutman, H. \& Hutton, P. (Eds) (1988) Technologies of the Self. London: Tavistock.

Marx, K. (1904) A Contribution to the Critique of Political Economy, 2nd edn, trans. N.I. Stone. New York: London: International Library Publishing Company.

Marx, K. (1967) Critique of Hegel's Philosophy of the State [1843], in Lloyd D. Easton \& Kurt H. Guddat (Eds) Writings of the Young Marx on Philosophy and Society. New York: Doubleday/Anchor.

Marx, K. (1973) Grundrisse: foundations of the critique of political economy, trans. Martin Nicolaus. New York: Vintage Books.

Marx, K. (1977) Theses on Feuerbach, in Karl Marx: selected writings, ed. David McLellan. Oxford: Oxford University Press.

May, T. (1994) Difference and Unity in Gilles Deleuze, in C.V. Boundas \& D. Olkowski (Eds) Gilles Deleuze and the Theatre of Philosophy, pp. 1-33. New York: Routledge.

Nietzsche, F. (1967) On the Genealogy of Morals. Ecce Homo, trans. Walter Kaufmann. New York: Random House.

Olssen, M. (1999) Michel Foucault: materialism and education. Westport: Bergin \& Garvey.

Olssen, M. (2003) Totalitarianism and the Repressed Utopia of the Present: moving beyond Hayek, Popper and Foucault, Policy Futures, 1(3). Available at: http:// www.triangle.co.uk/PFIE/

Pettit, P. (1997) Republicanism: a theory of freedom and government. Oxford: Oxford University Press.

Poster, M. (1984) Foucault, Marxism, History: mode of production vs mode of information. Cambridge: Polity Press.

Rabinow, P. (Ed.) (1984) The Foucault Reader. New York: Pantheon.

Rawls, J. (1971) A Theory of Justice. Oxford: Oxford University Press. 
Sappington, A.A. (1990) Recent Psychological Approaches to the Free Will versus Determinism Issue, Psychological Bulletin, 108, pp. 19-29.

Sardar, Z. \& Abrams, I. (1999) Introducing Chaos. Cambridge: Icon Books.

Saussure, F. de (1974) Course in General Linguistics. London: Fontana.

Schrift, A.D. (1995) Nietzsche's French Legacy: a genealogy of poststructuralism. New York and London: Routledge.

Sheridan, A. (1980) Michel Foucault: the will to truth. London and New York: Routledge.

Skarda, C.A. \& Freeman, W.J. (1990) Chaos and the New Science of the Brain, Concepts in Neuroscience, 1, pp. 275-285.

Swinney, H.L. (1983) Observations of Order and Chaos in Nonlinear Systems, Physica, 7, pp. 3-15.

Thompson, K. (1986) Beliefs and Ideologies. Chichester: Ellis Harwood.

Veyne, P. (1997) Foucault Revolutionizes History, in Arnold Davidson (Ed.) Foucault and His Interlocutors. Chicago and London: University of Chicago Press.

Williams, R. (1980) Problems in Materialism and Culture. London: Verso.

MARK OLSSEN is Professor and Director of Doctoral Programmes in the Department of Political, International and Policy Studies, University of Surrey. He is author of many books and articles in New Zealand. More recently he is author of Michel Foucault: materialism and education (Bergin $\&$ Garvey, 1999). He has published articles in Britain in the Journal of Education Policy, Policy Futures in Education, the British Journal of Educational Studies, Educational Psychology, the British Journal of the Sociology of Education, and Educational Philosophy and Theory. He is a co-editor with Michael Peters $\&$ Colin Lankshear of Critical Theory and the Human Condition: founders and praxis (Peter Lang, 2003) and, also with Michael Peters \& Colin Lankshear, of Futures of Critical Theory: dreams of difference (Rowman \& Littlefield, 2003). He is the author (with John Codd \& Anne-Marie O'Neill) of Education Policy: globalisation, citizenship, democracy (Sage, 2004) and of an edited volume, Culture and Learning: access and opportunity in the classroom (Information Age, 2004).

Correspondence: Mark Olssen, Department of Political, International and Policy Studies, University of Surrey, Guildford GU2 7XH, United Kingdom (m.olssen@surrey.ac.uk). 